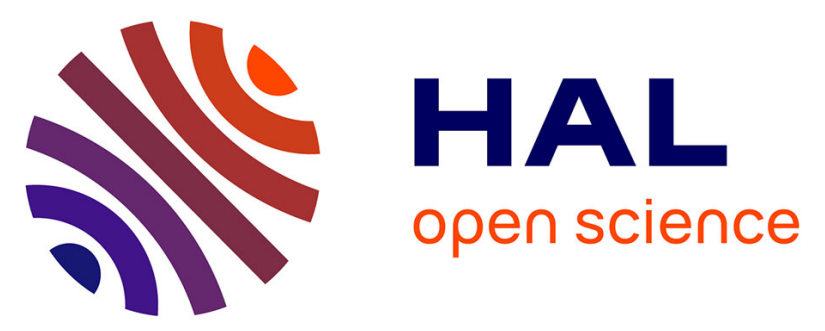

\title{
Palaeo-stress regimes and structural framework during the Mesozoic-Cenozoic tectonic evolution of the Crimean Mountains (the northern margin of the Black Sea)
}

Yevgeniya Korniyenko-Sheremet, Marc Sosson, Anna Murovskaya, Valentina Gobarenko, Tamara Yegorova

\section{To cite this version:}

Yevgeniya Korniyenko-Sheremet, Marc Sosson, Anna Murovskaya, Valentina Gobarenko, Tamara Yegorova. Palaeo-stress regimes and structural framework during the Mesozoic-Cenozoic tectonic evolution of the Crimean Mountains (the northern margin of the Black Sea). Journal of Asian Earth Sciences, 2021, 211, pp.104704. 10.1016/j.jseaes.2021.104704 . hal-03162333

\section{HAL Id: hal-03162333 https://hal.science/hal-03162333}

Submitted on 25 Nov 2021

HAL is a multi-disciplinary open access archive for the deposit and dissemination of scientific research documents, whether they are published or not. The documents may come from teaching and research institutions in France or abroad, or from public or private research centers.
L'archive ouverte pluridisciplinaire HAL, est destinée au dépôt et à la diffusion de documents scientifiques de niveau recherche, publiés ou non, émanant des établissements d'enseignement et de recherche français ou étrangers, des laboratoires publics ou privés. 


\section{Journal Pre-proofs}

Palaeo-stress regimes and structural framework during the Mesozoic-Cenozoic tectonic evolution of the Crimean Mountains (the northern margin of the Black Sea)

Yevgeniya Korniyenko-Sheremet, Marc Sosson, Anna Murovskaya, Valentina Gobarenko, Tamara Yegorova

PII: S1367-9120(21)00042-0

DOI: https://doi.org/10.1016/j.jseaes.2021.104704

Reference: JAES 104704

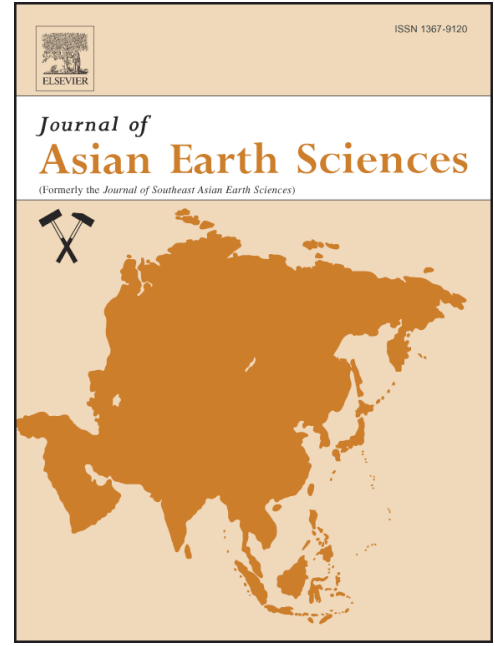

To appear in:

Journal of Asian Earth Sciences

Received Date:

27 August 2020

Revised Date:

20 January 2021

Accepted Date:

1 February 2021

Please cite this article as: Korniyenko-Sheremet, Y., Sosson, M., Murovskaya, A., Gobarenko, V., Yegorova, T., Palaeo-stress regimes and structural framework during the Mesozoic-Cenozoic tectonic evolution of the Crimean Mountains (the northern margin of the Black Sea), Journal of Asian Earth Sciences (2021), doi: https://doi.org/ 10.1016/j.jseaes.2021.104704

This is a PDF file of an article that has undergone enhancements after acceptance, such as the addition of a cover page and metadata, and formatting for readability, but it is not yet the definitive version of record. This version will undergo additional copyediting, typesetting and review before it is published in its final form, but we are providing this version to give early visibility of the article. Please note that, during the production process, errors may be discovered which could affect the content, and all legal disclaimers that apply to the journal pertain.

(C) 2021 Published by Elsevier Ltd. 


\title{
Palaeo-stress regimes and structural framework during the Mesozoic-Cenozoic tectonic evolution of the Crimean Mountains (the northern margin of the Black Sea)
}

Yevgeniya Korniyenko-Sheremet $^{1 *}$, Marc Sosson $^{1}$, Anna Murovskaya $^{2}$, Valentina Gobarenko $^{3}$, Tamara Yegorova ${ }^{2}$

1* sheremet@geoazur.unice.fr Université Côte d'Azur, CNRS, Observatoire de la Côte d'Azur, IRD, Géoazur, 250 rue A. Einstein, 06560, Valbonne, France. Tel. : +33 (0) 762397803

2 Institute of Geophysics, National Academy of Sciences of Ukraine, Pr. Palladina 32, 03680, Kiev, Ukraine.

3 V.I. Vernadsky Crimean Federal University, Institute of Seismology and Geodynamics, Simferopol.

\begin{abstract}
This paper presents a chronology of tectonic events in the Crimean Mountains (CM) based on a micro- (palaeo-stress) and macro-scale (tectonic structures) structural analysis since the Cretaceous. Recent studies have attempted to fit the geology of the CM into the geodynamic context of the subduction of the Neotethys plate beneath the Eurasian margin; however, these attempts remain difficult and controversial as they are based dominantly on stratigraphic analysis. New structural analysis results indicate that structural development within the CM was largely determined by the influence of pre-existing structures that occurred long before the Cretaceous rifting in the Black Sea (BS). This could explain the features of the geological structure in the Western and Eastern CM separated by the Alushta-Simferopol Fault Zone (ASFZ). New palaeo-
\end{abstract}


stress analysis allows us to identify the trends and timing of the Mesozoic-Cenozoic tectonic deformations with greater precision. Superimposing the low-magnitude seismicity $(\mathrm{M} \leq 3)$ with structures defined on the established geological cross-sections permit the localization of currently active structures. Considering both recent scientific achievements concerning the geology of the $\mathrm{CM}$ and the results of this study, we propose a qualitative model of the formation of the BS Basin and its inversion in the context of the BS-Greater Caucasus (GC). In this model, the Shatsky Ridge (ShR), moving to the north, acts as an indenter deforming the CM and the GC. The results are of practical importance for geodynamic modelling and hydrocarbon exploration.

Keywords: Crimean Mountains, Black Sea; palaeo-stress; tectonic evolution; structural analysis

\section{Introduction}

The long-term subduction of the Tethys oceanic plate beneath the Eurasian margin was a geodynamic process that influenced the development of the GC-BS region, of which the CM occupies an integral part (Fig. 1A) (Adamia et al., 1974, 1981; Angelier et al., 1994; Barrier et al., 2018; Barrier and Vrielynck, 2008; Dercourt et al., 1986; Ershov et al., 1999, 2003; Finetti et al., 1988; Khain, 1974; Letouzey et al., 1977; Milanovski, 1991; Nikishin et al., 1998, 2003, 2015c; Robinson et al., 1996; Saintot \& Angelier, 2002; Saintot et al., 2006; Sengör et al., 1980; Sosson et al., 2016; Stampfli et al., 2002; Stephenson \& Schellart, 2010; Vincent et al., 2016, Zonenshain \& Le Pichon, 1986). The CM is a relatively small geological area, $\sim 160-180 \mathrm{~km}$ long with a maximum width of 50 to $60 \mathrm{~km}$, and its highest summit reaches $1500 \mathrm{~m}$. However, determining the tectonic stages of the $\mathrm{CM}$ during the tectonic evolution of the $\mathrm{GC}-\mathrm{BS}$ domain remains difficult and controversial (e.g. Saintot et al., 2006). Often, the proposed scenarios of the tectonic evolution of the CM are either limited to a description of stratigraphic features, making casual remarks about 
the tectonic structures (e.g. Nikishin et al., 2015c), or focus on only one tectonic stage in the history of the CM (e.g. Hippolyte et al., 2018); moreover, the tectonic evolution of the CM in many studies did not consider the tectonic evolution of the regional context of the BS (e.g. Yudin, 2011).

Nevertheless, recent geological studies devoted to new age determination (Ivanik et al., 2013; Nikishin et al., 2017; Oszczypko et al., 2017, Popadyuk, 2011, Popadyuk et al., 2013a, b; 2014; Sheremet et al., 2014, 2016a) and analysis of tectonic structures of the CM (Hippolyte et al., 2018; Nikishin et al., 2017; Sheremet et al., 2016a, b) allowed the correlation of tectonic stages in both regions between the $\mathrm{CM}$ and the $\mathrm{GC}$ since the Early Cretaceous. The micro-tectonic analysis of the CM facilitated the determination of the directions of principal stresses (palaeo-stress fields). Detailed works of structural analysis at the micro- and macro-scale by Saintot et al. (1999) and Saintot and Angelier (2002) have been conducted for the CM and Kerch Peninsula (KP) (Fig. 1B) before the new dating information was obtained. Therefore, the stress-field obtained by these authors within the Triassic-Middle Jurassic age flysch rocks, specifically for the Eastern part of the CM, should be reconsidered given their newly defined Cretaceous age (Ivanik et al., 2013; Oszczypko et al., 2017; Popadyuk et al., 2011, 2013a, b; 2014; Sheremet et al., 2014, 2016a). Therefore, this paper is about presenting new palaeo-stress results for the Eastern part of the CM. These new results are going to presented in the context of new geological cross-sections (built taking into account the recent results of the stratigraphy) and localization data of low magnitude $(\mathrm{M} \leq 3)$ seismicity along the geological cross-sections, which are described and presented in section 3 and 4 before documenting new plaeo-stress results.

As the CM outcrops reveal a much older geological history of this region, this work focuses on structures that formed long before the Cretaceous rifting of the BS (e.g. the Late Triassic rifting and the Early-Middle Jurassic extension) but were observed to have a significant impact on 
tectonic development. These structures, deep crustal faults, have been reactivated over the late Mesozoic and Cenozoic tectonic stages of deformation (Sheremet et al., 2019). This study was conducted with specific consideration to the reactivation timing of pre-existing structures and the trends and timing of the tectonic deformations during the Mesozoic-Cenozoic geological history of the CM. This paper demonstrates why there is a difference in geological structures between the western and eastern parts of the CM, and proposes a tectonic evolution of the CM in the context of the $\mathrm{GC}-\mathrm{BS}$ domain.

\section{Tectonic setting and morphology of the Crimean Mountains}

The Crimean Peninsula is represented by a mountain domain (the CM) in its south; to the north, it is covered by Cenozoic deposits forming a northwest-dipping monocline in the Crimea relief - the Northern Crimea Lowland (NCL) (Fig. 1B). The continental crust of Crimea and adjacent offshore shelf areas of the BS and the Azov Sea belong to the southern margin of the Eastern European Platform, commonly called the Scythian Platform or the Scythian Plate (SP). The structural heterogeneity of the Crimean crust, revealed by tomography images (Yegorova et al., 2018), can be explained by various tectonic events that occurred during the tectonic evolution of the Eurasian Plate. These include 1) the late Proterozoic-Early Palaeozoic tectonic stage (Saintot et al., 2007, Stephenson et al., 2004, Yegorova et al., 2018; Ziegler, 1988) during which the SP most likely became the southern rigid margin of the East European Plate (or Platform) and 2) the Late Palaeozoic Variscan orogeny that resulted in the occurrence of slightly metamorphic rocks, which are interpreted as the basement rocks of Crimea (e.g. Muratov et al., 1969, Muratov et al., 1984; Okay \& Topüz, 2017). Moreover, since the late Permian, the SP has served as a part of the overriding plate (Laurasia) in the subduction process of the Tethys oceanic plate (e.g. Saintot 
et al., 2006). For example, the thickness of the crust beneath the Eastern BS and the Mid Black Sea Ridge (MBSR) and the ShR (Fig. 1B) is different: the Moho is at $20-22 \mathrm{~km}$ and $\sim 32 \mathrm{~km}$ depth under the Eastern BS and under the ridges, respectively (Yegorova \& Gobarenko 2010, Yegorova et al., 2010). This difference in thickness most likely indicates a significantly extended continental crust of the Eastern BS (Yegorova \& Gobarenko 2010, Yegorova et al., 2010).

The relief of the CM formed as a result of the collisional tectonic events related to the Tethys closure and represents an inverted part of the northern BS shelf due to the Cenozoic compressional stages (Gobarenko et al., 2016; Sheremet et al., 2016 b; Stephenson et al., 2004; Stephenson \& Shellart, 2010; Sydorenko et al., 2017; Ushakov et al., 1977). The CM are organized in three almost parallel and very large hogbacks ('yaylas') with very steep southern frontal slopes and gentle northern slopes. The highest elevations around 1200-1500 m comprise the mountain chain of the CM. The heights of the CM gradually decrease to the north to 250-350 m where they meet transition to the NCL (or the 'Steppe-like' Crimea).

\section{The geology of the Crimean Mountains}

To the geology of the CM, undoubtedly, numerous studies are devoted. But purely for the sake of integrating and interpreting the new results of this paper (the paleo-stress results) we present the summary of the geological features of the CM taking into account new dating results, obtained recently and documented in Popadyuk et al. (2013a, b), Sheremet et al. $(2014,2016 a)$ and Oszczypko et al. (2017). As a visual aid we propose a figure 2, which is composed of two maps juxtaposed: 1) a structural map of the Eastern part of the CM from Sheremet et al. (2016a) and 2) a geological map of Muratov et al. (1969), which was updated here with results of new dating of rocks (Sheremet et al., 2016a). To show stratigraphic features of the CM we appeal to a 
figure 3 published earlier for the eastern part of the $\mathrm{CM}$ in Sheremet et al. (2016a) but supplemented for this study with stratigraphic columns built for the western part of the CM, taking into account new datings of rocks published in Sheremet et al. (2016a) and Hippolite et al. (2018).

The structural framework of the CM presented in section 3.3 is illustrated with two pairs of geological cross sections, shown on figure 4: the cross section for the western part of the CM were built taking into account the compiled map on a figure 2, while the cross sections for the eastern part of the CM, which we use in the current study for the comparison, are reproduced fragments of the transects from Sheremet et al. (2016b). Additionally, before presenting data on paleostress, it is necessary to show a map of tectonic structures (fig.5), which was built on a base of existed geological data (Hippolite et al., 2018; Muratov et al., 1969; Murovskaya et al., 2018; Sheremet et al., $2016 \mathrm{a}, \mathrm{b})$ and our structural data gathered in the field.

\subsection{Pre-Cretaceous stratigraphy and structural forming in the $\mathrm{CM}$}

The oldest rock outcropping in the CM, the Tauric Formation (TFm) or Tavrica (Muratov et al., 1984; Nikishin et al., 2015c; Sheremet et al., 2016a; Slavin 1986) is penetrated by several wells around the Crimean Peninsula (e.g. Khriachtchevskaya et al., 2010). This is a succession of thick, dark-coloured shales with intercalations of siliciclastic turbidites, siltstones, and conglomerates in its upper part containing blocks (olistoliths) of Permian and Carboniferous limestones (Fig. 2) (Muratov, 1960, Nikishin et al., 2015c, Sheremet et al., 2016a and references therein). TFm contains magmatic bodies of the Late Triassic age, interpreted as sills (e.g. Spiridonov et al., 1990b). The TFm is very similar to the same flysch-like deposits in the Northern Dobrogea tectonic province (Romania), to the west of the CM (Fig. 1A). This area is located within the same latitudes as the CM, where the Upper Triassic flysch rocks seal the surface of the Middle Triassic limestones and contain pillow lavas, debris flow, and slumps in their lower part (Gradinaru, 1995). 
The occurrence of turbiditic formations with olistostromes (deposited on the marine slope) and active magmatism in both areas could be related to a period of subsidence by normal faulting in the Palaeozoic basement of the overriding plate (Laurasia) above the subduction of the Tethys plate during the Late Triassic. The trend of normal faulting was likely parallel to a subduction front interpreted to be of a $\sim \mathrm{E}-\mathrm{W}$ trend, according to the palaeogeographic reconstruction of the Tethys Ocean by Barrier \& Vrielynck (2008) and Barrier et al. (2018). Thus, these $\sim$ E-W faults could be understood as a first generation of normal faults within the southern Laurasian margin when the subduction starts. Many faults that border the North Azov Trough (Golitsin and Azov faults), which continues as the North Crimean Trough to the west and extends as Karkinit Trough in the Odessa Shelf, as well as the following tectonic units of the western BS shelf such as Gubkin and Kalamit Ridge, Zmeiniy uplift, and Krayova step also elongated in this $\sim \mathrm{E}-\mathrm{W}$ direction. Despite the fact (e.g. Khriachtchevskaya et al.,2010) that all of those tectonic structures were active during the Cretaceous, some of them are just reactivated early Mesozoic structures that attested their preCretaceous tectonic activity by thick accumulated lower Mesozoic deposits north of Zmeiniy Uplift (in the Dobrogea Depression) and south from the Azov Fault (on the Azov Ridge), what is visible from the interpreted seismic lines by Khriachtchevskaya et al., 2010. These $\sim \mathrm{E}-\mathrm{W}$ normal faults, attested from wide-angle refraction and reflection (WARR) velocity model superimposed on the NE-SW seismic line DOBRE-2 crossing the Azov sea, KP, and BS (Starostenko et al., 2017) were also determined by the morphotectonic analysis of the CM (Saintot et al., 1999). During the Latest Triassic-Earliest Jurassic compression, known as the Cimmerian orogeny (Eo or Early Cimmerian), these faults were reactivated and the TFm of the CM as well as their analogues around the BS (Kure Fm in the central Pontides, Dizi Fm in the GC) were deformed (Barrier \& Vrielynck, 2008; Mileev et al., 2009; Nikishin et al., 2015c; Okay, 2000; Okay \& 
Nikishin, 2015; Okay et al., 2015; Robinson et al., 1996; Saintot et al., 1999; Sengör, 1979, 1984, 1987; Sengör et al., 1985; Tari et al., 1997; Ustaömer \& Robertson, 1994; Yudin, 2008, 2009 , 2011; Zonenshain \& Le Pichon, 1986 ).

The evidence of the Cimmerian tectonics in the CM is only present westward of the valley joining Alushta and Simferopol (A-S) (Fig. 1B), where the compressional south verging structures (folds and reverses faults) in the TFm are covered with unconformity by the Hauterivian sandy limestones (unconformity U2) (Fig. 3, Fig. 4) (e.g. Murovskaya et al., 2012, 2014; Saintot et al., 1999; Sheremet et al., 2016a).

The Cimmerian deformations were also described to the east of A-S (Saintot et al., 1999). However, recent studies (Ivanik et al., 2013; Popadyuk, 2011, Popadyuk et al., 2013a, 2014; Oszczypko et al., 2017; Sheremet et al., 2014, 2016a;) have shown the Cretaceous age of the flysch rocks, which were previously described as TFm rocks. The position of the Cretaceous rocks under the Jurassic limestones in the Eastern CM has been explained by thrusting and demonstrated in Sheremet et al. (2014, 2016a). The compressional deformations to the east of the A-S probably occurred in post-Cretaceous timespan and are therefore Alpine in age (Sheremet et al., 2014, 2016a).

The middle Jurassic flysch-rocks are more calcareous in the upper part of its succession and unconformably cover the TFm (Unconformity U1, Fig. 3 and Fig. 4) (Muratov, 1960; Muratov et al., 1969). The TFm is intruded by Middle Jurassic magmatic rocks (Fig. 3, Fig. 4) (e.g. Dovgal' et al., 1991; Kazantcev et al., 1989; Lebedinskij \& Shalimov, 1967; Leshchuh et al., 1999; Meijers et al., 2010; Muratov, 1960; Okay et al., 2015; Solov'ev \& Rogov, 2010; Spiridonov et al., 1990a, b; Teslenko \& Yanovskaya, 1990; Nikishin et al., 2015c), which originated in magmatic arc settings related to northward subduction below the Eurasian margin based on 40Ar/39Ar dating 
and the geochemical analysis (Meijers et al., 2010). Thus, some tectonic structures that formed earlier (e.g. during the Triassic) were reactivated during the Middle Jurassic back-arc extension of the overriding plate; new micropalaeontological findings of detritic deposits along the $\sim \mathrm{E}-\mathrm{W}$ fault south of Simferopol ('Bitak formation' mostly consisting of conglomerates and with coal seams in some places) show that they were deposited during the Middle Jurassic (Nikishin et al., 2017) (Fig. 1B, Fig. 2, Fig. 3).

Additionally, beginning from the Early-Middle Jurassic, the GC area experienced a rifting stage related to the formation of the GC back-arc basin, followed by the occurrence of normal faults parallel to a NW-SE strike of the GC (the 'Caucasian' trend) (Adamia et al., 1981, Kaz'min \& Tikhonova, 2006 a,b; McCann et al., 2010; Nikishin et al., 1998, 2001, Saintot \& Angelier, 2002, Saintot et al., 2006; Sydorenko et al., 2017). The system of NW-SE trend faults could be attributed to a second generation of normal faults, which became dominant for the BS-GC domain from the Early-Middle Jurassic. In the vicinity of the future CM, this system of faults (fault zone) played an important role in the tectonic evolution of the $\mathrm{CM}$ and influenced the stratigraphy features and structural patterns of the areas termed Western Crimean Mountains (WCM) and Eastern Crimean Mountains (ECM) (Fig. 1B). This wide fault zone ( $>14 \mathrm{~km}$ wide) is referred to as Krivorozhsko-Samsunskiy Fault Zone (Lebedev \& Orovetzky, 1966), Salgir-Oktyabrskaya (Gintov, 2005; Gintov et al., 2009; Gonchar, 2005; Patalakha et al., 2003), or ASFZ (Saintot et al., 2006; Sheremet et al., 2016a; Spiridonov et al., 1990a, b) (Fig. 1B). This zone has been active several times since at least the Middle Jurassic (Gintov, 2005; Lebedev \& Orovetzky, 1966; Okay \& Nikishin, 2015; Saintot et al., 2006; Sheremet et al., 2016a). It justified its activity by (a) sharp changes in the stratigraphy of both regions (Fig. 3) (Abashin et al., 1982; Himshiashvili 1967; Lysenko \& Janin 1979; Mileev et al., 2004, 2009; Muratov 1960; Tkachuk 1970; Sheremet et al., 
2016a), (b) the distribution of the Middle Jurassic magmatism (Afanasenkov et al., 2007; Dubois de Montpereaux, 1843; Muratov, 1960; Leshchuh et al., 1999; Lebedinskij \& Shalimov, 1967; Nikitina et al., 1979; Sludskij, 1917; Yamnychenko, 1969; Zaika-Novackij, 1981; Zolotarev, 1968; among many others), and (c) the location of seismicity (e.g. Gobarenko et al., 2016). The offset of the NW-SE trending normal faulting of the 'Caucasian strike' (Saintot et al., 2006) bounds the ShR in the Eastern BS, while to the west, they bound the MBSR (Western Crimean Fault, WCF) (Fig. 1B).

The Middle Jurassic rocks of the CM are overlain transgressively by various marine facies (limestones and basinal marine facies) of Late Jurassic age (Karlov, 1963; Kazantcev et al., 1989; Mileev et al., 2004; Robinson \& Kerusov, 1997), which is likely due to the activation of the aforementioned $\sim \mathrm{E}-\mathrm{W}$ and NW-SE faults. For example, the age of Upper Jurassic limestones of the ECM and WCM (Nikishin et al., 2015 a, b, Oszczypko et al., 2017; Rudko et al., 2017 Sheremet et al., 2014, 2016a) changes from west to east; in the WCM, the carbonate-rich rocks are dated as late Kimmeridgian-Tithonian (based on $87 \mathrm{Sr} / 86 \mathrm{Sr}$ isotope measurements: Rudko et al., 2017), while to the east from ASFZ, the eastern termination of the main ridge is composed of limestones of the Tithonian-Early Berriasian age (Andruhovich \& Turov 2002). It means that the area of WCM was elevated compared to the ECM during the Late Jurassic, as the WCM had a more suitable condition for the formation of the Upper Jurassic platform. The wide distribution of carbonate rich rocks could be an evidence of relatively stable tectonic activity in the Late Jurassic (mostly in the Tithonian), while the occurrence of flysch rocks at the end of Tithonian, normal faulting, and back-arc magmatism indicate a new tectonic stage in the geological history of the BS-GC Domain (Meijers et al., 2010; Sheremet et al., 2016a). 


\subsection{The stratigraphy of the CM since the Cretaceous.}

The Early Cretaceous began abruptly in the $\mathrm{CM}$ by a period of back-arc magmatism (volcanic massif Karadag in the ECM (Fig. 2), based on 40Ar/39Ar dating and geochemistry (Meijers et al., 2010; Shniukova, 2019) due to the subduction of the Neotethys beneath the Eurasian margin (Fig. 2, 3). Lower Cretaceous rocks, mainly of Valanginian-Albian age, are composed of a large variety of slope-basin deposits (carbonate dominated breccias, conglomerates, siliciclastic sediments, turbidites, shales, and a rhythmic flysch-like sequence) and olistostromes containing olistoliths of Upper Jurassic-Berriasian limestones (Fig. 3) (Dobrovolskaya et Salman 2008; Ivanik et al., 2013; Nikishin et al., 2015c; Oszczypko et al., 2017; Popadyuk et al., 2014; Rudko et al., 2017; Sheremet et al. 2016a;). Hauterivian reef limestones and sandy limestones unconformably cover Upper Triassic rocks in the WCM and the top of the Upper JurassicBerriasian rocks of the main ridge and northern hills in the ECM (Unconformity U2 on Fig. 3). Albian shales unconformably cover the Barremian series in the WCM and Hauterivian limestones west of the ECM (Unconformity U3, Fig. 3).

The Cenomanian rocks in the ECM lie unconformably on the Albian rocks (Unconformity U4, Fig. 3). There are several erosional surfaces inside the Upper Cretaceous formations (Muratov, 1960; Zaika-Novatckij et al., 1976; Alekseev et al., 2005; Khriachtchevskaia et al., 2010; Datcenko, 2012), and some stratigraphic horizons pinch out eastwards in the ECM (Datcenko, 2012). The Upper Cretaceous exhibits lithological differences: in the WCM, mostly calcareous marls and chalk limestones are present, whereas in the ECM, they are more terrigenous (Alekseev et al., 2005; Sheremet et al., 2016a).

The volcanic ash material that could be found in the matrix of the Lower Cretaceous olistostromes (Sheremet et al., 2016a), in the Cenomanian and Campanian strata (up to 2-3 cm 
thick) (Nikishin et al., 2013, 2015a) and the presence of volcanoclastic sandstones of Late Albian age in the WCM (Nikishin et al., 2015c) indicate magmatic activity during the Cretaceous rifting stage in the BS area (Krezsek et al., 2017; Okay \& Nikishin, 2015; Sosson et al., 2016; Tari, 2015).

The palaeocene succession, which is composed by shallow marine limestones, sandy limestones, siltstones, and sandstones (in the upper horizons), is significantly thicker in the ECM (up to $280 \mathrm{~m}$ ) than in the WCM ( 85-90 m) (Stratigraphy of the Ukrainian SSR, 1963) and covers the erosional surface of the Cretaceous strata.

The Lower-Middle Eocene deposits include small-sized nummulite-rich marls (Nikishin et al., 2015c) covered by nummulitic limestones of the Middle Eocene. The thickness of the Eocene nummulitic limestones changes from $10 \mathrm{~m}$ to 40-45 m (Lygina, 2010; Datcenko, 2012). The Eocene unconformity (U6 on Fig. 3), overlying Lower Cretaceous to Palaeocene rocks, is well known in the CM (Datcenko, 2012; Geology of USSR, 1969, Kazantcev, 1982; Kazantcev et al., 1989; Muratov, 1960; Nikishin et al., 1999, 2003, 2015c; Pivovarov \& Derenyuk, 1984; Popadyuk et al., 2013a, b, 2014; Yudin, 2008, 2009, 2011) and can be identified on the seismic lines offshore the CM (Sheremet et al., 2016b). The pre-Eocene erosion in the CM ranges from $100 \mathrm{~m}$ to $500 \mathrm{~m}$ (Nikishin et al., 2015b, c).

The Oligocene-Early Miocene deposits (Maikopian Formation, MFm) are composed of grey, brown, or reddish clays with siderite concretions and gypsum (Vernyhorova \& Ryabokon, 2020). The thickness of the MFm strata reaches $110 \mathrm{~m}$ in the WCM foothills and $280 \mathrm{~m}$ in the ECM foothills (e.g. Muratov, 1960). These series, interpreted as syntectonic terrigenous deposits during the inversion of the GC basin (e.g. Adamia et al., 2010, 2011), unconformably cover the Middle Eocene nummulitic limestones or Upper Eocene marls (Fig. 2) (e.g. Muratov, 1960). The MFm sediments are locally present in the WCM (Pivovarov and Derenyuk, 1984) but they are 
absent (possibly eroded; Datcenko, 2012) in the area near Simferopol. In the ECM, the MFm appears only in the north-eastern part of the Kubalach Hills directly on the Middle Eocene limestones (Fig. 2, Fig. 4) (Afanasenkov et al., 2007; Datcenko, 2012 and references therein; Geology of USSR, 1969; Muratov, 1960; Nikishin et al., 2015a, b).

The terrigenous sediments (marine sandy and clay deposits) of the Middle Miocene (40$100 \mathrm{~m}$ thick) are marked in the CM by their angular unconformity on the erosional surface of the MFm in the west end of the ECM, while in the far western WCM (Cape Fiolent), they cover the Middle Jurassic volcanic rocks (including pillow lavas) (Datcenko, 2012; Geology of USSR 1969; Nikishin et al., 2006) (Fig. 2).

The Middle Miocene series is capped by the Upper Miocene (Sarmatian) shallow marine facies (limestones, clays, sandstones, and sands), indicating an overall regressional trend. The Upper Miocene succession varies in thickness from 35 to $120 \mathrm{~m}$ (Geology of USSR, 1969). It unconformably lies on Middle Eocene limestones and sometimes overlies the Upper Cretaceous chalky limestones (north of Zuya Village, Fig. 2), covered by continental deposits of the Middle Pliocene.

\subsection{Main structures of the CM}

Comparing the structures of the CM to the east and west from the deep NW-SE ASFZ (Fig. 4), it is possible to notice similarities in the tectonic style of deformations within the turbiditic units. However, the ages of the deformed rocks in WCM and ECM are different (Upper TriassicMiddle Jurassic and Cretaceous, respectively). The eastern sections (Fig. 4) are characterized by the widespread occurrence of Upper Mesozoic, mostly Cretaceous, sediments (see Sheremet et al., 2016a for the details) and represent structures formed by Cenozoic shortening. In contrast, marked by the Hauterivian unconformity U2 (Fig. 3), the WCM sections (Fig. 4) expose the Upper 
Triassic-Middle Jurassic slope sediments and compressional deformations of the Cimmerian orogeny in the TFm (e.g. Nikishin et al., 2015c; Okay, 2000; Okay et al., 2013; Okay \& Nikishin, 2015; Robinson et al., 1996; Sengör, 1979, 1984, 1987; Sengör et al., 1985; Ustaömer \& Robertson, 1993, 1994; Yudin, 2009, 2008, 2011; Zonenshain \& Le Pichon, 1986). However, considering the scale of Cenozoic deformations in the ECM, it is clear that the Cimmerian deformations in the WCM underwent a second compression during the Cenozoic (Murovskaya et al. 2014). This interpretation proposed on the cross-sections view (Fig. 4) indicates that preexisting structures played an important role in determining the location of the Cenozoic thrust.

The main thrust zone of the ECM (Sheremet et al., 2016a), traced west from the ChatyrDag massif ('yayla') (WCM) (Fig. 2 and Fig. 5) is displaced by strike-slip system faults (Gintov et al., 2003; Gintov 2005; Gonchar, 2005, 2013), which cross the elevated part of the WCM with TFm (termed the 'Crimean structural high') (Fig. 5) (Byzova 1980; Saintot et al., 2006). The results of the structural analysis (Hippolyte et al., 2018; Murovskaya et al., 2018) allow the definition of these structures as Cretaceous normal faults reactivated during the Cenozoic compressional tectonic stage as strike-slip faults (Balavadze et al., 1968; Gobarenko et al., 2016; Hippolyte et al., 2018; Murovskaya et al., 2018; Sheremet et al., 2016a; ). The thrust zone could be traced to the west of the Cape Ay-Todor (Fig. 1B, Fig. 5) where the Jurassic limestones overthrust the latest Jurassic-Early Cretaceous flysch sediments (Oszczypko et al., 2017; Sheremet et al., 2016a).

In addition to the compression structures formed in the Cenozoic, in the nummulite limestones of the Middle Eocene, we noted numerous synsedimentary normal faults with a $\sim \mathrm{SW}-$ NE trend (Fig. 6), which evidence extension during the deposition of the Eocene succession. 


\section{Localization of deep structures, active at present}

4a. Low magnitude seismicity

Usually, the microseismicity (low magnitude, $\mathrm{M} \leq 3$ ) can lead to imprecise location data and is dependent on the type of recording array used, but it is possible to employ it for the approximate trace in-depth the structures (fault zones), determined by geological field data. By cumulations of seismic records in the vicinity of the $\mathrm{CM}$ we can evaluate the tectonic activity of these structures at present.

The study area (Southern Crimea and adjusted northern margin of the BS) is characterized by seismicity within the Crimean Seismic Zone (CSZ) located northwestward of the seismically active Greater Caucasus orogen. The CSZ is defined by the earthquakes of $M=3-5$ with foci in the crust and upper mantle and abundant weak seismicity $(\mathrm{M} \leq 3$ ) (Yanovskaya et al., 2016; Gobarenko et al., 2016).

We studied the seismicity of the CSZ using data from weak earthquakes registered on- and off-shore in this region (the Crimean Seismic Zone, CSZ) during the period of 1970-2013 by nine permanent seismic stations of Crimea seismic network (shown by black triangles on Fig. 7A) on the Crimea Peninsula (at Feodosiya (FEO), Yalta (YAL), Simferopol (SIM), Sevastopol (SEV), Alushta (ALU), Sudak (SUDU), Kerch (KERU), Tarhankut (TARU), Donuzlav (DON)) and by the Anapa station on the Caucasian coast (Pustovitenko, 1991; 2010).

To specify the parameters of the earthquake foci (location and depth), relocation procedure has been used for the P-and S-wave arrivals at all permanent stations of Crimea seismic network. The relocated seismic data on weak earthquakes were used not only to study the seismicity distribution (of the study region) and its relation with recent tectonics, but also (and primarily) to 
restore the velocity structure of the crust of Southern Crimea and adjusted northern part of the BS by local seismic tomography (Gobarenko et al., 2017, Gobarenko and Yegorova 2020 a, b).

Within the study region (CM and adjusted northern part of the BS) two major subzones are recognized in the CSZ: Yalta-Alushta (Yuzhnoberezhnaya) and Sudak (subzones 2 and 3 in Fig.7a). The Yalta-Alushta subzone is known for generating a majority of densely located earthquakes with foci depth at 10-40 km, arranged by several stripes of N-S and NNW-SSE onshore in the $\mathrm{CM}$ and offshore on the BS continental slope within the area with $\lambda \approx 34^{\circ}-34.7^{\circ}$ (Fig. 7A; Gobarenko et al., 2016). The Yalta-Alushta subzone is limited from the west by an orthogonal subzone (Sebastopol subzone (labeled as subzone 1 in Fig. 7a)) characterized by scattered seismicity down to a depth of $40 \mathrm{~km}$. The Sudak subzone, with a small number of earthquakes clustered at the continental slope to a depth of $35 \mathrm{~km}$, shows a tendency to plunge northward (below the CM). The deepest earthquakes (with focal depths in the range 70-90 km depth) occur below the Kerch Peninsula shelf and Caucasus coast (subzone 4 in Fig. 7a) with foci deepen northwards (Gobarenko et al., 2016; 2017).

We used the data of weak seismicity $(M \leq 3)$ (Fig. 7a) to interprete the location of tectonic structures depending on the location of cumulative clouds of hypocentres (Fig. 8) placed along the geological cross-sections and transects we constructed (Fig. 4). As it is seen in Fig 7a, two active tectonics provinces (Gobarenko et al., 2017, 2016), Yalta-Alushta (Yuzhnoberezhnaya) and Sudak, are separated by the ASFZ. Transects a and b (Fig. 8) illustrate the distribution of earthquake loci in the eastern part of the Sorokin Trough. It is possible to see domains with ruptures that could correspond to the south verging fault zones (Fig. 8B). These structures are diagnostic for proposing underthrusting along the Crimea-GC deep thrust fault (Gobarenko et al., 2017, 2016). The faults along the external zone of GC are interpreted as Cenozoic reverse faults and 
thrusts (Mosar et al, 2010; Tan \& Taymaz, 2006). A sub-horizontal dashed line on Fig. 8 could correspond to a decollement level that marks the underthrusting between the BS and the CM, interpreted by Yegorova et al. (2018) based on DSS data, as an inversion zone in the upper crust with decreased velocities.

The images of the distribution of earthquake loci along the western geological crosssections (Fig. 8A) do not allow the definition of the vergence of structures. The hypocenters seem to be distributed uniformly along the represented cross-sections, which could correspond to vertical structures (faults) parallel to the cross-section to be viewed, possibly, strike-slip faults. This complex spread of loci could account for the impact of NW-SE Early-Middle Jurassic and Cretaceous normal faults (Hippolyte et al., 2018), which were reactivated as strike-slip faults during the Cenozoic compression (Fig. 5; Gobarenko et al., 2016). One of these faults, the WCF that bounds the MBSR from the west, is well traced by loci as a NW-SE trending zone off-shore western Crimea (Fig. 8) (Krezsek et al., 2017; Nikishin et al., 2015a, b; Okay \& Nikishin 2015; Tari et al., 2015, Yegorova et al., 2018). Its activation explains the widespread occurrence of earthquakes with strike-slip mechanisms westward of the CM (Gobarenko et al., 2016). Additionally, the character of loci distribution in the western BS area could be explained by the complex composition of the crust of the CM, revealed by seismic methods to be high-velocity heterogeneities and deep intrusive bodies, with the largest one located within the ASFZ (Yegorova et al., 2018).

4b. Focal mechanisms of the strongest earthquakes 
The existence of the southverging fault zones is supported by the focal mechanisms of the strongest earthquakes (Mw>3) defined during 1927-2016 (Gobarenko et al., 2016 Pustovotenko and Eredzhepov, 2017) for CSZ (see Table 1, Fig. 7, and Fig. 8: A on profiles SR and NM, B on profile BA).

Events 7, 14, 31 correspond to reverse, 1, 15 - to normal, 6, 8- to thrust mechanisms (Fig. 7). Events 4, 13, 21, 26, 27 show reverse and strike-slip components. The Andrusov ridge is characterized by a compression deformation regime, revealed in foci 20,23 , and 29 . The focal mechanisms of Kerch-Taman foci cluster correspond mainly to reverse faulting. Mechanisms with a significant strike-slip component are located in the western part of the CSZ. The orientations of the compressional axes in the foci indicate shortening with transpressive component for the current tectonic stage.

We projected 7 foci of the earthquakes (Table 1) located within north BS continental margin and the CM on the closest geological cross sections (Fig. 8) and plotted their focal mechanisms. Within ECM three earthquakes $(8,14,16)$ are in the continental crust with depths ranging from $20 \mathrm{~km}$ to $40 \mathrm{~km}$ (Fig. $8 \mathrm{~B}$ ). One of nodal planes of 14 is steeply $\left(60^{\circ}\right)$ northward dipping, and the focal mechanism evidence a reverse component on this plane which could correspond to the rupture along a main thrust (see figure $8 \mathrm{~B}$, a). The mechanism of the earthquake number 8 with a low angle nodal plane of landward dipping is located almost at the bottom of foci cluster's distribution and possibly corresponds to a detachment within the lower crust. In WCM, the projected hypocenters $(6,7,31)$ are shallower and are located along the northward dipping rupture zone of low angle (Fig. 8A).

The focal mechanisms of the strongest earthquakes defined in the CM evidence an active southward thrusting, with some transpressive component, within the continental crust. The 
geometry of the compressional structures in the vicinity of the $\mathrm{CM}$ that correspond to an underthrusting process within the southern margin of Crimea (Gobarenko et al, 2015, 2016) allows us to define the ShR as the indenter. Considering crustal heterogeneities, mentioned earlier, the ShR could be responsible for the formation of compressional structures of the CM and of its offshore.

5. New Palaeo-Stress Data of the Eastern Crimean Mountains

As the results of structural analysis of the CM presented in works of Sheremet et al. (2014, 2016a, b) and Hippolyte et al. (2018) allowed synchronizing the tectonic stages defined for the $\mathrm{CM}$ and the $\mathrm{GC}$, the use of the palaeo-stress analysis can allow the clarification of these tectonic shortening/extension event trends. A new fault kinematic analysis was applied to rock-complexes of the ECM using new age dating from the TFm in this region (Ivanik et al., 2013; Nikishin et al., 2017; Oszczypko et al., 2017; Popadyuk, 2011, Popadyuk et al. 2013a, b; 2014; Sheremet et al., 2014, 2016a); the outcrops with the flysch rocks of the TFm in the ECM are limited in space, because they are covered by the Lower Cretaceous flysch deposits. Therefore, compressional deformations that some authors (e.g. Saintot et al., 1999) have attributed to Cimmerian orogeny are corresponding to Cenozoic compression and must be reconsidered in light of the collisional processes south of the BS, which are linked to the closure of the Neotethys oceanic plate from the Late Cretaceous to Early Palaeocene in the east (region of Lesser Caucasus; Rolland et al., 2012; Sosson et al., 2010) and from the Palaeocene to Eocene in the west (region of Pontides; Espurt et al., 2014; Lefebvre et al., 2013; Okay \& Nikishin, 2015; Okay \& Tüysüz, 1999; Robertson et al., 2014; Sengör et al., 2003).

5.1 Method and data 
We based our analysis on outcrop scale fault slip data (919 slickensides and calcite slickenfibres measured in 50 outcrops) (Table 2, Fig.9). For the processing and interpretation of the slickensides, the kinematic method was applied using the 'Win-Tensor' program (Delvaux \& Sperner, 2003) along with 'Stereonet' (Allmendinger et al., 2012) to build the stereograms, considering the methodology of Sperner \& Zweigel (2010), Hippolyte et al. (2012), and Lacombe (2012).

For each site, we determined the palaeo-stress regime (reverse, normal, or strike-slip). Since the main tectonic events are identified quite precisely according to the results of structural analysis (macroscale) (Hippolyte et al., 2018; Sheremet et al., 2014, 2016a,b), the main purpose of using microtectonic analysis (palaeo-stress) was to clarify the directions of the principal stresses (palaeo-stress field) of known tectonic stages. Considering that our data were selected exclusively from the Mesozoic rocks, it is not possible to determine the relative age of existing tectonic regimes, for example, in the Cenozoic solely by the method of fault slip data inversions. Therefore, to extract Cenozoic palaeo-stress, we compared our results with those in published materials (e.g. Gintov, 2005; Hippolyte et al., 2018; Murovskaya et al., 2012, 2014, 2018; Saintot et al., 1999; Saintot and Angelier, 2000).

\subsection{Resulting palaeo-stress regimes}

\subsubsection{Reverse regime}

For the majority of sites in the ECM, we obtained a large display of reverse regimes with $\sigma_{1}$ (greatest compressive stress) trending NW-SE (western part of the sector) and NNW-SSE (eastern part of the sector) (Fig. 9A, Table 2). This supports the results of the structural analysis both onshore and offshore, including the trends of thrust zones and fold axes, $\mathrm{S}_{0}$-dipping analyses on 
stereograms, and the orientation of the thrust front (Sheremet et al., 2016a, b) (Fig. 9A). The trends of compression vary locally; in the area of Sudak city, it is a N-S compression (site 24, Fig. 9A), and in the vicinity of Ordzhonikidze, the trend of compression was defined as NNE-SSW by the fold axis trend analysis (Fig. 6A).

\subsubsection{Strike-slip regime}

The analysis of the structural patterns in the ECM (Sheremet et al., 2016a) (Fig. 2, Fig. 5) revealed several NE-SW and NNE-SSW trending faults with left-lateral strike-slip motion. These strikeslip faults cut and displaced several thrusts and thrust fronts in several localities (Fig. 2, Fig. 5) (Sheremet et al., 2016a). In the rocks of the Miocene-Pliocene units, we defined a right-lateral displacement along the NW-SE strike-slip faults. A strike-slip regime with a N-S orientation of $\sigma_{1}$ and an E-W orientation of the $\sigma_{3}$ was also detected in the very eastern part of the ECM (Fig. 9B; Table 2). According to the structural data, these strike-slip faults postdate the main thrust of the CM. We suggest that the $\mathrm{N}-\mathrm{S}$ trend of the compression characterizes the youngest tectonic stage of the ECM.

At several locations (stereodiagrams 17, 57, and 65; Fig. 9B) we obtained strike-slip regimes with an almost $\mathrm{E}-\mathrm{W}$ orientation of compressional axis $\sigma_{1}$. Sites 17 (open pit in Grushevka village) and 57 (limestone close to the Karadag region) (Fig. 9B) belong to a very large Upper Jurassic limestone massif, which could possibly be a block. Site 65 is located near Hauterivian limestones close to Mezhgorye village.

The strike-slip regimes with a NW orientation of $\sigma_{1}$ were obtained mostly in the western part of the ECM (stereodiagrams 43, 37; Fig. 9B, Photo in Fig. 6B). A strike-slip regime with a clear $\mathrm{N}-\mathrm{S}$ orientation of $\sigma_{1}$ and an almost $\mathrm{E}-\mathrm{W}$ orientation of the $\sigma_{3}$ was detected locally for the eastern part of the ECM (stereodiagram 3; Fig. 9B). 


\subsubsection{Normal regime}

North of Alushta, the Demerji Mountain (Fig. 1B, 2) (site 50; Fig. 9C, Table 2) is located in the area of the ASFZ, which is considered to be one of the major deep structures of Crimea (Byzova 1980; Gintov, 2005; Khain 1984; Koronovskiy 1984; Morgunov et al., 1979; Saintot et al., 1999; Sollogub 1977; Volfman 2015) it shows a NE-SW direction of extension. The same trend of extension was identified close to Dachnoe village (site 22, north of Sudak city) (Fig. 9C, Table 2).

We identified an E-W extensional regime (sites 61 and 56; Fig. 9C, Table 2) in several places of the ECM. The structural data observed around the village of Druzhnoe reveal a normal fault with an almost N-S strike near the Dolgorukovskaya Yayla (Fig. 6C). The hanging wall is Upper Jurassic-Berriasian limestone whereas the western foot-wall of this fault is red breccia. In the ECM, the red calcareous conglomerate-breccia of Early Cretaceous age overlies the Upper Jurassic limestones north of Karabi Yayla (Sheremet et al., 2016a), which is likely related to the normal faulting that occurred during Cretaceous rifting.

The results also indicate extensional regimes with a NW orientation for $\sigma_{3}$ (Fig. 9C), which is perpendicular to the orientation of the compressional structures.

6. Meso-Cenozoic stress history of the CM: integrated results and discussion

The structural frame within the CM during the late Mesozoic and the Cenozoic is predetermined by pre-existing structures (Saintot et al., 1999; Sheremet et al., 2016b.). The chronological summary of the tectonic stages and stress regimes obtained for the whole $\mathrm{CM}$ in this section based on the structural and stratigraphic control of the macro scale data, taking into account published studies containing new results on the dating of rocks and structures of the CM (Hippolyte 
et al., 2018; Murovskaya et al., 2012, 2014, 2018; Saintot et al., 1999; Saintot \& Angelier, 2000) with references to the subduction-collisional geodynamic settings of the BS-GC domain.

\section{Extensional deformations during the Cretaceous.}

A large quantity of data on the palaeo-stress field in the CM is related to the normalfaulting. In the WCM, the stress fields are characterized by N-S and NNE-SSW extensions (Hippolyte et al., 2018; Saintot et al., 1999;), whereas in the ECM, the orientation of $\sigma_{3}$ corresponds to a NE-SW trend (Fig. 9C), which is supported by Saintot et al. (1999). In that study, the authors identified NW-SE normal faults (N140) parallel to the strike of the ASFZ and active during the Cretaceous. For the WCM, other than the NW-SE strike of the faults, Saintot et al. (1999) also pointed out the WNW-ESE (N105 and N110) strike as important Cretaceous faults with N-S $\sigma_{3}$ orientation.

We suggest that the difference in the structural pattern in the WCM and the ECM during the Cretaceous could be explained by the specific position that the territory of the future peninsula occupied. As mentioned, the eastern part of the peninsula was influenced by the extensional NWSE faults of the 'Caucasian' trend since the Early-Middle Jurassic, the ASFZ is one of these faults that separates the ECM and WCM (Byzova, 1980; Lebedev \& Orovetskiy, 1966; Saintot et al., 2006). In the backdrop of the GC basin's loading in the vicinity of the ECM, an eastward deepening slope was formed during the Hauterivian-Aptian, which was characterized by the distribution of olistostromes with the olistoliths of the Upper Jurassic-Berriasian limestone, flysch, grainstones, conglomerates, and coarser turbiditic material (Dobrovolskaya \& Salman 2008; Ivanik et al., 2013; Nikishin et al., 2015c; Oszczypko et al., 2017; Popadyuk et al., 2014; Sheremet et al., 2016a; Sosson et al., 2016) (Fig. 10). The results of DSS and local seismic tomography (Yegorova et al., 2018) show an eastward dipping Mesozoic surface in the vicinity of Feodosia, which could be 
interpreted as a normal fault; this occurred due to the deepening of the GC (Fig. 10). The WCM seem to be uplifted (Afanasenkov et al., 2007; Byzova, 1980; Dubois de Montpereaux, 1843; Lebedev and Orovetskiy, 1966; Lebedinskij \& Shalimov, 1967; Leshchuh et al., 1999; Muratov, 1960; Nikitina et al., 1999; Saintot et al., 2006; Sludskij, 1917; Zaika-Novackiy, 1981; Zolotarev, 1968; Yamnychenko, 1969;) compared to the ECM (see stratigraphic logs Fig. 3). The data indicates a later onset (Valanginian-Barremian) of the rifting stage in the WCM (as opposed to the late Jurassic rifting in the ECM), which has been related to the reactivation of the NW-SE ASFZ (Murovskaya et al., 2014; Hippolyte et al., 2018; Saintot et al., 1999).

The Cretaceous normal faults with the $\sim \mathrm{E}-\mathrm{W}$ strike in the WCM (Murovskaya et al. 2012; 2014; Saintot et al., 1999) may have occurred owing to the reactivation of pre-existing Triassic normal faults; the major extensional features in the overriding plate may have formed due to the subduction of the palaeo-Tethys (Barrier et al., 2018). These structures extend to the west from the CM up to the Northern Dobrogea where they are limited by another deep crustal NW-SE fault zone: the Trans European Suture Zone (e.g. Hippolyte et al., 2002; Săndulescu et al., 1978; Seghedi et al., 2005; Winchester et al., 2006). These similar $\sim \mathrm{E}-\mathrm{W}$ structures have also been observed in the Balkanides (Bergerat, et al., 2010; Doglioni et al., 1996, Georgiev et al., 2001). Regarding the $\mathrm{CM}$, the $\sim \mathrm{E}-\mathrm{W}$ faults are notable on the DOBRE-2 CDP profile (Sydorenko et al., 2016) and are revealed by seismic interpretation to the north of the CM (e.g. Khriachtchevskaia et al., 2010). The reheating of the Eurasian margin during the Cretaceous (Aptian-Albian) as a result of the subduction of the spreading centre of the Ankara-Erzincan-Sevan-Akera (AESA) oceanic backarc basin (Sosson et al., 2016) (Fig. 1a) and/or the Tethys's slab roll-back (Stephenson \& Schellart, 2010) reactivated these Triassic $\sim \mathrm{E}-\mathrm{W}$ and middle-Jurassic NW-SE structures as normal faults. It is likely that the ShR and MBSR became significant morphological 'Caucasian' units of the BS's 
palaeorelief and were separated during the aforementioned period (Sheremet-Korniyenko, 2016).

This could explain why two oblique directions of faults formed during the Cretaceous within the CM (Fig. 11).

\section{Early Cenozoic compression in the CM}

Since the end of the Maastrichtian, some areas of the BS domain underwent compressional tectonics due to the final closure of the northern branch of the Neotethys (Barrier and Vrielynck, 2008; Dercourt et al., 1986; Okay \& Tüysüz, 1999; Sosson et al., 2010; 2016; Yilmaz et al., 1997; Zonenshain \& Le Pichon, 1986), however, the CM underwent the shortening since the Palaeocene (Sheremet et al., 2016a,b). A reverse regime with $\sigma_{1}$ trending NW-SE is the main one that we defined for the CM. The NW-SE direction of the $\sigma_{1}$ compressional axis prevailed during the formation of the main compressional structures (thrusts, folding) onshore and offshore the CM and in the south-western part of the KP (fig.5) (Gerasimov, 1992; Saintot \& Angelier, 2000; Sheremet et al., 2016a, b).

By the time when shortening begins, the lithosphere and crust of the Eastern BS was not cooled enough to had sufficient mechanical strength to deform the continental Crimean margin: after the rifting ("lithosphere stretching") it, was composed of horsts and grabens represented by thick and stretched continental crust with different rheological behaviour. Under the compressional settings, deformation of more brittle behaviour were performed between the blocks with thick continental crust (e.g. the Crimean margin and the ShR), while the very streched parts of the BS lithosphere could experiense ductile deformations. It could facilitate the inversion of the thick continental blocks of the crust, including their displacement along the faults, that consequently, could contribute to an extension, especially in the central parts of the BS's sub-basins. The latter, 
however, were interpreted as the real opening of the BS during the Cenozoic (e.g. Maynard and Erratt, 2020).

The ShR (relic of the continental crust) was presumably perpendicular to the future CM at this time (Fig. 11). As a result of the collision to the south (Taurides-Anatolides-South Armenian continental microplate, fig. 1a)) with Eurasia, (e.g. Sosson et al., 2010, 2016), the ShR acted as an indenter and triggered the inversion of the pre-existing (Triassic-Cretaceous) extensional structures. Consequently, the pre-existing normal faults of different strikes underwent reactivation progressively (Hippolyte et al., 2014, 2018; Murovskaya et al., 2018; Sheremet et al., 2016b; Sosson et al., 2016). Shortening due to underthrusting of the Cretaceous extended crust beneath the $\mathrm{CM}$ caused intensive erosion of the raising $\mathrm{CM}$ and resulted in thick Palaeocene-lower Eocene sequences that filled the Sorokin Trough (Sheremet et al., 2016b; Sheremet-Korniyenko, 2016; Sydorenko et al, 2016). The presence of thick Palaeocene sediments in the Sorokin Trough is correlated with the Subbotina well $\log$ (Sheremet et al., 2016b) and attested by an isobaths map showing the top of the middle Palaeocene terrigenous sediments in the Sorokin Trough (Tari et al., 2011). The time estimation of the early shortening within the CM since the Palaeocene is in agreement with the results of the apatite fission-track thermochronology (Panek et al., 2009) that interpreted the uplifting of the CM within the Early-Middle Eocene. The absence of the Uppermost Cretaceous-Palaeocene sediments in the Simferopol area-likely the result of the uplifting of the CM-further supports this correlation (e.g. Zaika-Novackiy et al., 1976).

\section{Normal regime with $N W-S E$ orientation of $\sigma_{3}$}

We obtained the normal regime with NW-SE orientation of $\sigma 3$ in the Mesozoic rocks which coincides with the extension trend extracted from normal synsedimentary faults in the Eocene limestones (Fig. 6). The results show that their formation postdates the compression that 
began in the Palaeocene. The NW-SE orientation of $\sigma 3$ in the extensional regimes is parallel to the NW-SE direction of the $\sigma_{1}$ compressional axes responsible for the formation of initial folds and thrusts in the CM (Sheremet et al., 2016a). The NE-SW strike of the extensional structures is also noticeable in the scarp of the present day seafloor of the ECM's offshore slope (Saintot et al., 1999). We propose that the extension occurred synchronously to the uplifting of the CM. Data from the wells of the Azov and Black Seas and the Odessa shelf show terrigenous lithologies for Eocene sediments (shales, siltstones, and marls) (Khriachtchevskaia et al., 2010), and their ageanalogue deposits within the CM are the nummulitic limestones. This indicates that the uplifted position of the CM may be due to shortening, thus causing some compression structures to become normal faults under a gravitational instability (relaxation of compressional stresses). The occurrence of synsedimentary normal faults in the Middle Eocene nummulitic limestones is related to the formation of a piggyback basin to the north of the rising folds and thrusts of the CM.

Since the Late Eocene, shortening in the BS has been reactivated (Bosworth and Tari, 2020; Khriachtchevskaia et al., 2010; Nikishin et al., 2015c; Sheremet et al., 2016a, b; Stovba et al., 2009; Tari et al., 2018).

\section{Reverse regime with NS orientation of $\sigma_{1}$}

The structures formed under the $\mathrm{N}-\mathrm{S}$ shortening were observed in the Sudak-city area and KP (Saintot and Angelier, 2000). Previously, a N-S compression extracted from the flysch-rocks of the Sudak-city area was interpreted as shortening during the Cimmerian orogeny (Saintot et al., 1999). As the results of the new dating of these rocks show the Early Cretaceous age (Ivanik et al., 2013; Oszczypko et al., 2017; Popadyuk et al., 2013a, 2014; Sheremet et al., 2014, 2016a;), we suggest that the palaeo-stress reconstructions reflect post-Cretaceous deformations, which have superimposed on the early Mesozoic Cimmerian shortening. The structural data at the micro and 
macro scale of the KP (Kazantcev \& Bekher, 1988; Saintot et al., 1999; Saintot \& Angelier, 2002) shows that the $\mathrm{N}-\mathrm{S}$ trend for $\sigma_{1}$ characterizes the latest phase of compression. The folds and thrusts of the E-W strike in the Middle Pliocene marine sediments of the KP overthrust those formed under the NNW-SSE compression (i.e. ENE-WSW oriented folds of the Parpatch Ridge, southwest of the KP) (Saintot \& Angelier, 2002). This means that changes in the trend of shortening (from NW-SE to N-S) post-date the Middle Pliocene deposition (Fig. 11). This conclusion is supported by the changes in the deformation regime within the CM (from reverse to strike slip); the $\sigma 1$, extracted from strike-slip faults in the youngest marine sediments of Miocene-Pliocene of the CM, has a N-S trend (Gintov, 2005; Gonchar, 2013; Murovskaya, 2012; Saintot et al., 1999; Volfman, 2014).

\section{Strike-slip regime postdating the reverse regime in the CM}

As shown on the structural map (Fig. 2, Fig. 5) and by the data, the strike-slip faults cut several thrusts and displaced the thrust fronts of the CM.

The strike-slip regime in the WCM (Gobarenko et al., 2016; Murovskaya et al., 2014; 2018 ) is characterized by a NE-SW orientation of $\sigma_{1}$. Murovskaya et al. $(2017,2018)$ noted the presence of Cretaceous normal faults with a NW-SE strike in the WCM, which were reactivated during the Cenozoic shortening as dextral strike-slip faults (based on microtectonic measurements in outcrops). Some data correspond to a strike-slip regime with an almost E-W orientation of the compressional axis $\sigma_{1}$, for the ECM (stereodiagrams 17, 57, and 65; Fig. 9B). We derived two hypotheses from these results: first, these three sites may correspond to olistoliths within the Lower Cretaceous flysch, and therefore, the data are not representative due to rotation of the blocks during the deformation; second, these strike-slip faults may result from the reactivation of local structures. 
We argue that the changes in the principal stresses of the regimes and trends during the Cenozoic can be explained by the northward plunging of the Eastern BS extended crust (Yegorova et al., 2010) that contain relics of the continental crust, such as the ShR, under the CrimeanCaucasian margin (Fig. 11). Because of the oblique position of the ShR (NW-SE orientation) to the Crimean margin, its gradual relocation to the north and gradual plunging trigger the uplifting of the CM and then, with a delay, the uplifting of the KP in the Late Pliocene (Muratov, 1960; Pivovarov, 1984; Saintot et al., 1999;). The northward plunging of the Eastern BS, containing the oblique relics of the continental crust as ShR, could explain a clockwise progressive trough formation south of the CM: the formation of the Sorokin Trough began in the Palaeocene as shown by the age of the terrigenous sediments that infilled the trough (Sheremet et al., 2016b; Tari et al., 2011). The Kerch-Taman Trough is infilled with deposits of the Palaeocene-Eocene (Sheremet et al., 2016 b; Tari et al., 2011), while the Tuapse Trough formed during the Eocene-Oligocene (Robinson et al., 1996) (Fig.11). Thus, due to this obliquity, the shortening within the CMs' margin also acquires to a clockwise progressive change in its direction (from NW to NNW and even to N-S). Probably, this northward relocation of the ShR is reflected as changes in the regime from reverse to strike-slip that was previously suggested by Saintot et al., 1999.

A second Cenozoic stage of compression was identified as having a somewhat periodic character (Datcenko, 2012; Khriechtchevskaya et al., 2010; Stovba et al., 2012; Stovba et al., 2013). The gradual uplift of the ECM onshore is exemplified by several discontinuities and/or unconformities (depending on location) throughout the Miocene (Datcenko, 2012; Geology of USSR, 1969; Muratov, 1960; Muratov et al., 1969, 1973; Nikishin et al., 2006). This interruption in the deposition probably corresponds to the gradual plunging of the ShR under the CM (underthrusting of the ShR). However, in the WCM, the transpressional regime identified by 
Murovskaya et al. (2018) is the result of the reactivation of Cretaceous normal faults parallel to ASFZ as strike-slip faults (for example strike-slip WCF) (Murovskaya et al., 2018; Saintot et al., 1999;). A strike slip regime was also obtained by the study of local mechanisms of earthquakes in the Western CSZ (Gobarenko et al., 2016; Murovskaya et al., 2017, 2018) (Fig. 8). We suggest that their occurrence is linked to the stress field exerted on the MBSR by a strong sub-oceanic, or more probably, a highly extended continental crust of the Western BS under the ongoing compression, which occurred in the BS since the Tethys closure.

\section{Conclusions}

Tectonic evolution of the CM should be regarded as one of the consequences of the longstanding subduction of the Tethys oceanic plate under the Laurasian-European margin at least since the Early Mesozoic (e.g. Barrier et al. 2018; Barrier \& Vrielynck, 2010; Stampfli \& Borel 2002; Stampfli et al., 2001; van Hinsbergen et al., 2019). Throughout this process, in the overriding plate formed two systems of faults 1 ) of $\sim \mathrm{E}-\mathrm{W}$ trend, their origin could be linked to the extension most likely related to a Triassic rifting through the normal faults in the Eurasian basement, which were likely parallel to a subduction front (Barrier et al., 2018); and 2) NW-SE-trending faults originating from the Early-Middle Jurassic due to opening of the Caucasian domain in a back-arc setting (Zonenshain and Le Pichon, 1988). Both systems of faults were reactivated during the Early Cretaceous, which could explain the obliquity of cretaceous structures within the CM area. The pre-existed structures continue to impact the current seismicity distribution.

Our results of micro-/macro-scale structural analysis allow to identify the following periods of deformation and tectonic regimes with the palaeostress field orientations for the CM since the Cretaceous and to elucidated the possible mechanisms of tectonic development. 
1. The Cretaceous extension is evidencing by the NE-SW and ENE-WSW orientation of $\sigma 3$ obtained for the sites located along NW and NNW faults. Extensional deformations (the $\sigma 3$ orientation of NE-SW) started earlier in the ECM (Earliest Berriasian) (Sheremet et al., 2016a); the structural framework was parallel or very close to a NW-SE strike of the ASFZ, since it was most likely influenced by the NW-SE 'Caucasian' faults, related to a back-arc basin formation of the GC initiated since the Early-Middle Jurassic;. then, during Valanginian-Barremian the rifting process propagated to the SW and reached the WCM (Hippolyte et al., 2014, 2018; Murovskaya et al., 2014,) along the NW-SE and WNW-ESE trending normal faults.

2. The shortening within the CM that started in the Palaeocene due to the collision of the Tauride-Anatolides-South Armenian microplate (Fig. 1, No 8 in legend) and the Eurasian margin, exhibited a NW-SE trend, which produced the main compressional structures as folds and thrusts in the CM and KP of the NE-SW strike. Due to the thrust propagation to the SW (present offshore), the synsedimentary normal faults occurred on the back of the thrust unit (in the middle Eocene limestones). Thus, a piggy-back basin formed on top of the moving thrust sheets, producing a local extensional regime in the basin (within the CM) in the Middle Eocene (the NW trend of $\sigma 1$ in the frontal part is parallel to the trend of $\sigma 3$ in the piggyback basin). At one point during the Middle Pliocene, the trend of compression in the most eastern part of the CM and KP changed to $\mathrm{N}-\mathrm{S}$, which was then followed by changes in the tectonic regime from reverse to strikeslip in the CM.

We explain these trend changes, shortening, and tectonic regime evolution by the northward plunging of the extended BS crust, containing continental relics such as ShR in the oblique position to a general N-S direction of shortening, under the CM margin and, consequently, by gradual relocation of the ShR to the north. Owing to this, the Crimean Peninsula experienced 
underthrusting and the KP uplifted after a delay. We suggest that underthrusting since the Palaeocene triggered the clock-wise formation of troughs south of the CM: the Sorokin, Kerch Taman, and Tuapse troughs in the Eocene-Oligocene.

Acknowledgments

This study is a final part of the PhD work of Yevgeniya Sheremet (defended in 2016) supported by the Embassy of France in Kyiv, Ukraine. We are grateful to the participation of the IRG project 'South Caucasus Geosciences' of the CNRS/INSU (GDRI 776), which made this research possible. We express special gratitude to the DARIUS programme for its funding. The authors also confirm that the data concerning the seismicity stored in the Supplemental Material_seismicity Data Set SI, were uploaded to Figshare. The data are contained in published sources cited in the References (Hippolyte et al., 2018; Murovskaya et al., 2014, 2018; Oszczypko et al., 2017; Popadyuk et al., 2013a, b; Sheremet et al., 2016a, b; Yegorova et al., 2018). We are also grateful to Marc Hässig for his comments on the earlier version of the manuscript and to reviewers: Alexandr Kitchka, Gabor Tari, Randell Stephenson and to anonymous reviewer for their efficient work and rational criticism leading to improve the manuscript, and mainly to Randell Stephenson who helped in its reorganisation.

\section{References}

Abashin, A.A., Pasynkov, A.A., and Sidorenko, O.G. 1982 Rezultaty deshyfrirovaniya kosmicheskih snimkov Kryma (Results of decription of the space images of the Crimea). Tektonika I stratigrafiya, (2), 35-39 [in Russian].

Adamia, S., Gamkrelidze, I. P., Zakariadze, G. S., \& Lordkipanidze, M. V. 1974. Adjara-Trialeti trough and the problem of the Black Sea origin. Geotectonika, 1, 78-94 [in Russian]. 
Adamia, Sh. A., Chkhotua, T., Kekelia, M., Lordkipanidze, M., Shavishvili, I. and Zakariadze, G. 1981. Tectonics of Caucasus and adjoining regions: implications for the evolution of the Tethys ocean. Journal of Structural Geology, 3, 437-447.

Adamia, S., Alania, V., Chabukiani, A., Chichua, G., Enukidze, O., Sadradze, N. 2010. Evolution of the Late Cenozoic basins of Georgia (SW Caucasus): a review. Geological Society, London, Special Publications, 340(1), 239-259.

Adamia, Sh. A., Zakariadze, G., Chkhouta, T., Sadradze, N., Tsereteli, N., Chabukiani, A. and Gventsadze, A. 2011. Geology of the Caucasus: a review. Turkish Journal of Earth Sciences, 20, 489-544.

Afanasenkov, A.P., Nikishin, A.M., Obukhov, A.N. 2007. Eastern Black Sea Basin: geological structure and hydrocarbon potential, Moscow, Nauchnyj mir, 172 [in Russian].

Alekseyev, A.S., Kopayevich, L.F., Baraboshkin, Ye.Yu., Gabdulin, R.R., Olferyev, A.G. \& Yakovishyna, YE.V. 2005. Paleogeography of the south of Eastern-European platform and its folded margin in Late Cretaceous. Paper 1. In: Introduction and Stratigraphy Base. Bulletin of the Society of Naturalists Moscow, Geology Department, MGU, Moscow, 80, 80-92 [in Russian].

Almendinger, R. W., Cardozo, N., Fisher, D. 2012. Structural Geology Algorithms: vectors and tensors. Cambridge, England, Cambridge University Press., 289 p.

Andruhovich, A.O., Turov, A.V. 2002. Comparisonal characteristics of Tithonian - Berriasian deposits of Karabi and Demerji Yaylas (Crimea Mountains). Izvestiya VUZov. Geologiya i Razvedka, 2, 29-39 [in Russian].

Angelier, J., Gushtenko, O., Saintot, A., Ilyin, A., Rebetsky, Y., Vassiliev, N., Yakovlev, F., and Malutin, S. 1994. Relationships between stress fields and deformation along a compressive 
strike-slip belt: Caucasus and Crimea (Russia and Ukraine). C.R. Acad. Sci. Paris, 319, II, 341-348.

Balavadze B.K., Burakovskiy, V.E., Garkalenko, I.A., Golovinskiy, V.I., Goncharov, V.I., Gurevich, B.L., Korneev, V.I., Malovickiy, Ya.P., Milashyn, A.P, Neprrochnov Yu.P., Pustilnikov, M.P., Sollogub, V.B., Cereteli, V.I., Chekunov, A.V., Chernyak, N.I., Chirvinskaya, M.V., Shardanov, A.V. (1968). Tektonika oblasti Xernogo I Azovskogo morey (Tectonics of Balck Sea and Azov Sea regions) // Geotectonics, №4. C 70-84 [in Russian] Barrier, E. \& Vrielynck, B. (Contributors: Bergerat, F., Brunet, M.-F., Mosar, J., Poisson, A. \& Sosson, M.) 2008. Palaeotectonic Maps of the Middle East. Tectono-sedimentary-palinspastic Maps from Late Norian to Piacenzia. Commission for the Geological Map of the World (CGMW/CCGM)/UNESCO. (http://www.ccgm.org) Atlas of 14 maps, scale 1/18 500000.

Barrier E., Vrielynck, B., Brouillet J.F. \& Brunet M.F. (Contributors : Angiolini L., Kaveh F., Poisson A., Pourteau A., Plunder A., Robertson A., Shekawat R., Sosson M. and Zanchi A.) 2018.- Paleotectonic Reconstruction of the Central Tethyan Realm. TectononoSedimentary-Palinspastic maps from Late Permian to Pliocene. CCGM/CGMW, Paris, http://www.ccgm.org. Atlas of 20 maps (scale: 1/15 $000000)$.

Bergerat, F., Vangelov, D. and Dimov, D., 2010. Brittle deformation, palaeostress field reconstruction and tectonic evolution of the Eastern Balkanides (Bulgaria) during Mesozoic and Cenozoic times. Geological Society, London, Special Publications, 340(1), pp.77-111.

Bosworth, W. and Tari, G., 2020. Hydrocarbon accumulation in basins with multiple phases of extension and inversion: examples from the Western Desert (Egypt) and the Western Black Sea. Solid Earth Discussions, pp.1-31. 
Byzova, S.L. 1980. Some questions of the tectonics of the Crimea Mountains. Vestnik MGU, 4, 15-25 [in Russian].

Datcenko, A., 2012. Cenozoic unconformities in the foothils of the Crimea//Azov-Black Sea testing area for study the geodynamics and fluid dynamics of gaz and oil subsoils. Abstract volume of 10th International conference "Crimea 2012". Assosiation of geologists, Simferopol, pp. 238-246.

Delvaux, D. and Sperner, B. 2003. Stress tensor inversion from fault kinematic indicators and focal mechanism data: the TENSOR program. In: New Insights into Structural Interpretation and Modelling (D. Nieuwland Ed.). Geological Society, London, Special Publications, 212: 75100.

Dercourt, J., Zonenschain, L. P., Ricou, L. -E., Kazmin, V. G., Le Pichon, X., Knipper, A. L., Grandjacquet, C., Sbortshikov, I. M., Geyssant, J., Lepvir, C., Pechersky, D. H., Boulin, J., Sibuet, J. -C., Savostin, L. A., Sorokhtin, O., Westphal, M., Bazhenov, M. L., Lauer, J. P. and Biju-Duval, B. 1986. Geological evolution of the Tethys belt from the Atlantic to the Pamirs since the Lias. Tectonophysics, 123, 241-315.

Dobrovolskaya, T.I. \& Salman, G.B. 2008. Olistostromes of the Lower Cretaceous sediments in the Eastern Crimea. In: New to the Regional Geology of Russia and CIS: Proceedings of the Meeting. RSGPUPubl., Moscow, 30-34 [in Russian].

Doglioni, C., Busatta, C., Bolis, G., Marianini, L., \& Zanella, M. 1996. Structural evolution of the eastern Balkans (Bulgaria). Marine and Petroleum Geology, 13(2), 225-251.

Dovgal', Ju.M., Rodzivil, V.Ya., Tokovenko, V.S., Chernyavskiy, S.V. \& Mihalenok, D.K. 1991. Volcanoes of Karadag. Naukova dumka, Kiev [in Russian]. 
Dubois de Montpereaux, 1843. Voyage autour du Caucase. Chez les Tcherkessus et les Abkhases en Colchide, en Géorgie, en Arménie en Crimée. Librairie de Gide, Paris.

Ershov, A.V., Brunet, M.-F., Korotaev, M.V., Nikishin, A.M. and Bolotov, S.N. 1999. Late Cenozoic burial history and dynamics of the Northern Caucasus molasse basin: implications for foreland basin modelling. In: Stephenson, R.A., Wilson, M., Starostenko,V.I. (eds.), Intraplate Tectonics and Basin Dynamics of the Eastern European Craton and its Margins. EUROPROBE Georift. Vol. 2: Tectonophysics, 313, 219-241.

Ershov, A. V., Brunet, M. F., Nikishin, A. M., Bolotov, S. N., Nazarevich, B. P. and Korotaev, M.V. 2003. Northern Caucasus basin: thermal history and synthesis of subsidence models. Sediment. Geolog., 156, 95-118.

Espurt, N., Hippolyte, J. C., Kaymakci, N. and Sangu E. 2014. Lithospheric structural control on inversion of the southern margin of the Black Sea Basin, Central Pontides, Turkey. Lithosphere, 6, 1, 26-34, http://doi.org/10.1130/L316.1

Finetti, I., Bricchi, G., Del Ben, A., Pipan, M. and Xuan, Z. 1988. Geophysical study of the Black Sea. Bolletino di Geofisica ed Applicata, 30, 197-324.

Geology of USSR 1969. Geology of the USSR. Vol. VIII. The Crimea. Part 1. Geological Description, 576. Nedra, Moscow [in Russian].

Georgiev, G., Dabovski, C., Stanisheva-Vassileva, G., 2001. East Srednogorie - Balkan rift zone. In: Ziegler, P.A., Cavazza, W., Robertson, A.H.F., Crasquin-Soleau (Eds.), Peri-Tethys Memoir 6: Peri-Tethyan Rift/Wrench Basins and Passive Margins, vol. 186. Memoires Museum National d'Histoire Naturelle, Paris, pp. 259-293. 
Gerasimov M.Y. 1992. Tectonics of Mesozoic sediments and diapiric structures of the Kerch Peninsula. Geologiya nefti I gaza/ Geology of oil and gas, 9. http://geolib.ru/OilGasGeo/1992/09/Stat/stat04.html

Gintov,O.B., Gonchar, V.V., Belichenko, P.V., Lazarenko, O.E., Pryadun, M.L. and Petrichenko, N.V., 2003. On the need to improve the quality of the evidence base in support of the mobilistic concept of the development of the Crimean peninsula. In.: Problems of geodynamics and oil and gas potential of the Black Sea-Caspian region. Abstract vol. of $5^{\text {th }}$ International conference "Crimea-2003”. Simpheropol (pp.24-26).

Gintov, O.B. 2005. Field Tectonophysics and its Methodology for the Studying the Deformation of the Earth Crust of Ukraine. Feniks, Kiev [in Russian].

Gintov, O.B., Murovskaya, A.V. and Mychak, S.V., 2009. Complex usage of the structural and kinematic methods is a condition of the progress in the field tectonophysics. Tectonophysics and the actual questions of the Earth Science. For the $40^{\text {th }}$ jubilee of the creation of the laboratory of the Tectonophysics by M.V. Gzovskiy, p. 26 [in Russian]

Gobarenko, V., Yegorova, T., and Stephenson, R., Local tomography model of the northeast Black Sea: intraplate crustal underthrusting, in Tectonic Evolution of the Eastern Black Sea and Caucasus, Sosson, M., Stephenson, R.A., and Adamia, S.A., Eds., Geol. Soc.London Spec. Publ. Geol. Soc., London, 2017, vol. 428, pp. 221-239. https://doi.org/10.1144/SP428.2

Gobarenko, V.S., Murovskaya, A.V., Yegorova, T.P., Sheremet, E.E.: Collision processes at the northern margin of the Black Sea. Geotectonics 50, 407-424 (2016).

DOI: $10.1134 / \mathrm{S} 0016852116040026$ 
Gobarenko V., Yegorova T., 2020a. Seismicity and crustal structure of the Southern Crimea and adjiacent Northern Black Sea from local seismic tomography. In: Yanovskaya T.B. et al. (eds), Problems of Geocosmos-2018, Springer Proceedings in Earth and Environmental Sciences, p. 215-227. doi: 10.1007/978-3-030-21788-4_18

Gobarenko V.S., Yegorova T.P., 2020b. Seismic tomography model for the crust of Southern Crimea and adjacent northern Black Sea. Journal of Volcanology and Seismology, 2020, Vol. 14, No. 3, pp. 187-203. DOI: 10.1134/S0742046320030033

Gojik, P. F., Maslun, N. V., Plotnikova, L. F., Ivanik, M. M., Yakushin, L. M., \& Ischenko, I. I. (2006). Stratigraphy of Meso-Cenozoic Sediments of the North-Western Shelf of the Black Sea. Institute of Geological Sciences of the National Academy of Sciences of Ukraine, Kiev [in Russian].

Gonchar, V.V. 2005. Ductile and brittle deformations in the south-western part of the Crimea Mountains as a result of structural analysis. Bulletin MOIP, Geology Department, 80, 27-35 [in Russian].

Gonchar, V.V. 2013. The sequence of stress fields and age of folding of the eastern part of the Crimea Mountains. Geophysical Journal, 35, 170-175 [in Russian].

Gradinaru, E., 1995. Mesozoic rocks in North Dobrogea: an overview, in: M. Săndulescu \& E. Grădinaru (Eds), IGCP Project No. 369, Comparative Evolution of PeriTethyan Rift Basin. Central and North Dobrogea, Romania, October 1-4, 1995, Field Guidebook.

Graham, R., Kaymakci, N., \& Horn, B. W. (2013). The Black Sea: something different. Geo Expro, $10(5), 57-62$.

Himshiashvili, N.G. 1967.Late Jurassic Mollusc FaunaCrimea-Caucasus Region. Metsniereba, Tbilisi [in Russian]. 
Hippolyte, J-C., 2002. Geodynamics of Dobrogea (Romania): new constraints on the evolution of the Tornquist-Teisseyre Line, the Black Sea and the Carpathians. Tectonophysics, 357, 33-53. Hippolyte, J-C., Bergerat, F., Gordon, M., Bellier, O., Espurt, N.. 2012. Keys and pitfalls in mesoscale fault analysis and paleostress reconstructions, the use of Angelier's methods. Tectonophysics (2012), 10.1016/j.tecto.2012.01.012

Hippolyte, J-C., Murovskya, A., Müller, C., Volfman, Y., Yegorova, T., Gintov, O., Sosson, M., Sheremet-Korniyenko, Y. 2014. Preliminary study of cretaceous normal faulting in western Crimea. Abstract, Final Symposium of Darius Programme, December 8-9 2014 Paris, 66-67. Hippolyte, J.C., Murovskaya, A., Volfman, Y., Yegorova, T., Gintov, O., Kaymakci, N. and Sangu, E., 2018. Age and geodynamic evolution of the Black Sea Basin: Tectonic evidences of rifting in Crimea. Marine and Petroleum Geology, 93, pp. 298-314.

Ivanik, M.M., Zhabina, N.N. \& Anikeeva, E.V. 2013. The features of Tithonian-Berriasian sediments structure of South-Eastern Crimea (region of Svyatoy Illya Cape). Geologicheskiy Zhurnal., 4, 35-45 [in Russian].

Karlov, N.N. 1963. Oxford bioherms eastern part of Crimea. Izvestija VUZov. Geologija i Razvedka, 4, 41-46 [in Russian].

Kazantsev, YU.V. 1982. Tektonika Kryma [Tectonics of the Crimea]. Nauka, Moscow [in Russian].

Kazantsev, YU.V., \& Bekher, N. I. 1988. Allochthonous structures of the Kerch Peninsula. Geotectonics, 22(4), 346-355. [in Russian].

Kazantsev, YU.V., Kazantceva, T.T., Arzhavitina, M.YU., Arzhavitin, P.V., Beher, N.I., Terehov, A.A. \& Popovich, S.V. 1989. Structural Geology of the Crimea. Bashkir Scientific Center of Ural Department of the Academy of Science of the USSR, Ufa [in Russian]. 
Kazmin, V. G. \& Tikhonova, N., F. 2006a. Evolution of Early Mesozoic back-arc basins in the Black Sea-Caucasus segment of a Tethyan active margin, In Robertson, A. H. F. \& Mountrakis, D. (eds) 2006. Tectonic Development of the Eastern Mediterranean Region. Geological Society, London, Special Publications, 260, 179-200.

Kaz'min, V.G. and Tikhonova, N.F., 2006. Late Cretaceous-Eocene marginal seas in the Black Sea-Caspian region: paleotectonic reconstructions. Geotectonics, 40(3), pp.169-182.

Khain, V. Y., 1974. Structure and main stages in the tectono-magmatic development of the Caucasus: an attempt at geodynamic interpretation. American Journal of Science, 274, 16-23.

Khain, V.Y. 1984. Regional Geotectonics. The Alpine-Mediterranean Belt. Nedra, Moscow [in Russian].

Khriachtchevskaia, O., Stovba, S., and Stephenson, R. 2010. Cretaceous-Neogene tectonic evolution of the northern margin of the Black Sea from seismic reflection data and tectonic subsidence analysis. In: M. Sosson, N. Kaymakci, R. Stephenson, F. Bergerat, V. Starostenko (Eds.). Sedimentary Basin Tectonics from the Black Sea and Caucasus to the Arabian Platform. Geological Society, London, Special Publications, 340, 137-157, http://doi:10.1144/SP340.8

Koronovskij, N.V. 1984. The Scytian plate. In: Regional Geology of USSR. Moscow State University Press, 211-212 [in Russian].

Krézsek, C., Bercea, R.I., Tari, G. and Ionescu, G., 2017. Cretaceous sedimentation along the Romanian margin of the Black Sea: inferences from onshore to offshore correlations. Geological Society, London, Special Publications, 464, pp. SP464-10. 
Lacombe, O. 2012. Do fault slip data inversions actually yield "paleostresses" that can be compared with contemporary stresses? A critical discussion. C. R. Geoscience, 344, 3-4, 159173, https://doi.org/10.1016/j.crte.2012.01.006

Lebedev, T.S. and Orovetskiy, Y.P., 1966. Particularities of tectonics of the Crimean Mountains. Geophysical vol. of the Institute of Geophysiscs of the Academy of Scinece of Ukrainian SSR, (18) [in Russian]

Lebedinskij, V.I. \& Shalimov, A.I. 1967. Magmatism in the structure and geological history of the Crimea Mountains. Soviet Geology, 2, 82-97 [in Russian].

Leschukh, R.J., Permiakov, V.V. \& Polukhtovych, B.M. 1999. Jurassic Deposits of Southern Ukraine. Eurosvit, Lviv [in Ukrainian].

Lefebvre, C., Meijers, M.J.M., Kaymakci, N., Peynircioglu, A., Langereis, C.G., and Van Hinsbergen, D.J.J., 2013. Reconstructing the geometry of central Anatolia during the late Cretaceous: Large-scale Cenozoic rotations and deformation between the Pontides and Taurides: Earth and Planetary Science Letters, v. 366, p. 83-98. doi:10.1016/j. eps1.2013.01.003

Letouzey, J., Biju-Duval, B., Dorkel, A., Gonnard, R., Kritchev, K., Montadert, L. and Sungurlu, O., 1977. The Black Sea: a marginal basin; geophysical and geological data. In: B., BijuDuval, and L., Montadert, (eds.), International Symposium on the Structural History of the Mediterranean Basins, Technip,Paris, 363-376.

Lygina, E.A., 2010. Danian and Eocene Platforms of the Crimea: Build-up and Conditions of Formation (Doctoral dissertation, PhD Thesis) Moscow University, Moscow (in Russian). 
Lysenko, N.I. \& Yanin, B.T. 1979. Biostratigraphic characteristics of a typical section of the Upper Jurassic and Lower Cretaceous Central Crimea. Proceedings of the Academy of Science of the USSR, 6, 70-80 [in Russian].

McCann, T., F. Chalot-Prat, and A. Saintot. 2010. The Early Mesozoic evolution of the Western Greater Caucasus (Russia): Triassic-Jurassic sedimentary and magmatic history. In: M. Sosson, N. Kaymakci, R. Stephenson, F. Bergerat, V. Starostenko (Eds.). Sedimentary Basin Tectonics from the Black Sea and Caucasus to the Arabian Platform. Geological Society, London, Special Publications, 340, 181-238.

Maynard, James R., and Duncan Erratt. "The Black Sea, a tertiary basin: Observations and insights." Marine and Petroleum Geology (2020): 104462

Meijers, M. J. M., Vrouwe, B., van Hinsbergen, D. J. J., Kuiper, K. F., Wijbrans, J., Davies, G. R., Stephenson, R. A., Kaymakci, N., Matenco, L., Saintot, A. 2010. Jurassic arc volcanism on Crimea (Ukraine): Implications for the paleo-subduction zone configuration of the Black Sea region. Lithos, 119, 412-426. doi: 10.1016/j.lithos.2010.07.017.

Milanovsky, E. E. 1991. Geology of the USSR. P. 3. MSU Publ., Moscow, 416 [in Russian].

Mileev, V.S., Baraboshkin, E.JU., Rozanov, S.B. \& Rogov, M.A. 2004. Karadag paleovolcano position in the structure of the Crimea Mountains. In: Morozova, A.L.\&Gnyubkin, V.F. (eds) Karadag. History, Geology, Botany, Zoology: Collection of Scientific Papers Dedicated to the 90th Anniversary of the Karadag Scientific Station on Behalf of T.I. Viazemsky and the 25th Anniversary of the Karadag Nature Reserve. Book 1. Sonat, Simferopol, 68-93 [in Russian]. Mileev, V. S., Baraboshkin, E. Y., Rozanov, S. B., \& Rogov, M. A. (2009). Tectonics and geodynamic evolution of the Crimean Mountains. Byulleten obshchestva ispytateley prirody. Otd. geol, 84(3), 23 [in Russian]. 
Morgunov, YU.G., Kalinin, A.V., Kalinin, V.V., Kuprin, P.N., Limonov, A.F., Pivovarov, B.L. \& Shscherbakov, F.A. 1979. The principal elements in the tectonics of the southern flank of the Crimean mega-anticlinorium. Geotectonika, 13, 310-315 [in Russian].

Mosar J, Kangarli, T, Bochud, M, Glasmacher, U. A., Rast, A., Brunet M.-F. and Sosson, M. 2010. Cenozoic-Recent tectonics and uplift in the Greater Caucasus: a perspective from Azerbaijan. Geological Society, London, Special Publications, 340, 261-280, 14 September 2010, https://doi.org/10.1144/SP340.12

Muratov, M.V. 1960. A Brief Sketch of the Geological Structure of the Crimean Peninsula. State. Scientific and Engineering Publications on Geology and Subsoil Protection, Moscow [in Russian].

Muratov, M. V., (Eds.) 1969. Geology of USSR. Vol VIII. The Crimea. Part 1. Geological description. Moscow, Nedra, 1969. 576, and Map [in Russian]

Muratov, M. V. 1973. Geology of the Crimean peninsula. Rukovodstvo po uchebnoi geologicheskoi praktike v Krymu. T, 2 [in Russian].

Muratov, M.V., Arkhipov, I.V., Uspenskaya, Y.A., 1984. Structural evolution of the Crimean mountains and comparison with the western Caucasus and the eastern Balkan ranges. International Geology Review 26, 1259-1266

Murovskaya, A.V., 2012. The stress-strained state of the Western Mountainous Crimea in the Oligocene-Quaternary according to tectonophysical data. Geofizicheskiy zhurnal,34(2), pp.109-119 [in Russian]

Murovskaya, A., Hippolyte, J.C., Sheremet, E., Egorova, T., Volfman, Y. and Kolesnikova, E., 2014. Deformation structures and stress field of the south-western Crimea in the context of the evolution of western Black Sea Basin. Geodinamika (2), pp.53-68. 
Murovskaya, A.. Sheremet, Y., Sosson, M., Hippolyte, J.-C., Gintov, O., Yegorova, T. 2017. Paleo and recent stress regimes of the Crimean Mountains based on micro and macroscale tectonic analysis and earthquakes focal mechanisms. Abstract, Final Workshop of IRG South Caucasus Geosciences, Kiev 25-27 October 2017, Abstract Volume of Special publication of the Geophysical journal of the National Academy of Science of Ukraine.

Murovskaya, A., Hippolyte, J.C., Sheremet, Y. and Yegorova, T., 2018. Recent and paleo-stresses at the northern margin of the Black Sea and the Crimea Mountain in Meso-Cenozoic-Quarter (according to mechanisms of earthquakes foci and field tectonophysical data). Geofizicheskiy Zhurnal, 40(1), pp.42-65.

Nikishin, A. M., Cloetingh, S., Brunet, M.-F., Stephenson, R. A., Bolotov, N., Ershov, A. 1998. Scythian Platform, Caucasus and Black Sea region: Mesozoic-Cenozoic tectonic history and dynamics. In: S. Crasquin-Soleau, E. Barrier (Eds) Peri-Tethys Memoir 3: Stratigraphy and Evolution of Peri-Tethyan Platforms. Paris: Mémoires Muséum national d'Histoire naturelle. $163-176$.

Nikishin, A. M., Ziegler, P. A., Stephenson, R. A., \& Ustinova, M. A. 1999. Santonian to Palaeocene tectonics of the East-European craton and adjacent areas. Bulletin-Institut royal des sciences naturelles de Belgique. Sciences de la terre, 69, 147-159.

Nikishin, A. M., Ziegler, P. A., Panov, D. I., Nazarevich, B. P., Brunet, M.-F., Stephenson, R. A., Bolotov, S. N., Korotaev, M. V., Tikhomirov, P. L. 2001. Mesozoic and Cainozoic evolution of the Scythian Platform—Black Sea—Caucasus domain. In: P. A. Ziegler, W. Cavazza, A. H. F. Robertson, S. Crasquin-Soleau (Eds). Peri-Tethys Memoir 6: Peri-Tethyan Rift/Wrench Basins and Passive Margins. Paris: Memoires Museum national d'Histoire naturelle, 295-346. 
Nikishin, A. M., Korotaev, M. V., Ershov, A. V., Brunet, M. F. 2003. The Black Sea basin: tectonic history and Neogene-Quaternary rapid subsidence modelling. Sediment. Geol., 156, 149168.

Nikishin, A. M., Alekseev, A. S., \& Baraboshkin, E. Y. 2006. The geological history of the Bakhchisaray district of Crimea: Proc. Benefit Crimean practice), Moscow: Izd vo Mosk. State Univ.

Nikishin, A.M., Khotylev, A.O., Bychkov, A.Yu, Kopaevich, L.F., Petrov, E.I., Yapaskurt, V.O. 2013. Cretaceous volcanic belts and the Black Sea Basin history. Mosc. Univ. Geol. Bull., 68 3, 141e154. http://dx.doi.org/10.3103/ S0145875213030058.

Nikishin, A. M., Okay, A., I., Tüysüz, O., Demirer, A., Amelin, N., Petrov , E. 2015a. The Black Sea basins structure and history: New model based on new deep penetration regional seismic data. Part 1: Basins structure and fill. Marine and Petroleum Geology, 59, 638-655, doi:10.1016/j.marpetgeo.2014.08.017

Nikishin, A. M., Okay, A., I., Tüysüz, O., Demirer, A., Amelin, N., Petrov, E., 2015b. The Black Sea basins structure and history: New model based on new deep penetration regional seismic data. Part 2: Tectonic history and paleogeography. Marine and Petroleum Geology, 59, 656670, doi:10.1016/j.marpetgeo.2014.08.018

Nikishin, A.M., Wannier, M., Alekseev, A.S., Almendinger, O.A., Fokin, P.A., Gabdulin, R.R., Khudoley, A.K., Kopaevich, L.F., Mityukov, A.V., Petrov, E.I., Rubtsova, E.V. 2015c. Mesozoic to recent geological history of southern Crimea and the Eastern Black Sea region. In: Sosson, M., Stephenson, R.A. and Adamia, S. A. (eds) Tectonic Evolution of the Eastern Black Sea and Caucasus. Geological Society, London, Special Publications, 428, http://doi.org/10.1144/SP428.1 
Nikishin, A.M., Gabdullin, R.R., Makhatadze, G.V., Khudolei, A.K. and Rubtsova, E.V., 2017. Bitak conglomerates as a clue for understanding the Middle Jurassic geological history of Crimea. Moscow University Geology Bulletin, 72(1), pp.18-27.

Nikitina, M.I., Polskih, G.M. \& Suslov, A.V. 1979. About some geological-petrological particularities of little intrusions in the valley of the river Bodrak (Bahchisaray region of the Crimea). Izvestiya VUZov. Geologiya i Razvedka, 6, 39-43 [in Russian].

Okay, A. İ. 2000. Was the Late Triassic orogeny in Turkey caused by the collision of an oceanic plateau? Geological Society, London, Special Publications, 173(1), 25-41.

Okay, A. I., Sunal, G., Sherlock, S., Alt ner, D., Tüysüz, O., Kylander-Clark, A. R., \& Aygül, M. (2013). Early Cretaceous sedimentation and orogeny on the active margin of Eurasia: Southern Central Pontides, Turkey. Tectonics, 32(5), 1247-1271.

Okay, A. I., and Nikishin, A. M. 2015. Tectonic evolution of the southern margin of Laurasia in the Black Sea region, International Geology Review, 57:5-8, 1051-1076, DOI: $10.1080 / 00206814.2015 .1010609$

Okay, A. I., Altiner, D., and Kilic, A. M. 2015. Triassic limestone, turbidites and serpentinite-the Cimmeride orogeny in the Central Pontides. Geological Magazine, 152(03), 460-479.

Okay, A. I. \& Topuz, G. 2017 Variscan orogeny in the Black Sea region. International Journal of Earth Sciences, 106(2), 569-592.

Okay, A. I., \& Tüysüz, O. 1999. Tethyan sutures of northern Turkey. In: Durand.B., Jolivet, L., Horvath, E \& Seranne, M. (eds) The Mediterranean Basins:Tertiary Extension within the Alpine Orogen. Geological Society, London, Special Publications, 156, 475-515 
Oszczypko, N., Ślączka, A., Bubniak, I., Olszewska, B. and Garecka, M., 2017. The position and age of flysch deposits in the Crimean Mountains (Southern Ukraine). Geological Quarterly, 61(4), pp.697-722.

Panek, T., Danis`ik, M., Hradecky', J. and Frisch, W. 2009. Morpho-tectonic evolution of the Crimean mountains (Ukraine) as constrained by apatite fission track data. Terra Nova, 21, 271-278, http://doi.org/10.1111/j.1365-3121.2009.00881.x

Patalakha E. I., Gonchar V. V., Senchenkov I. K., Chervinko O. P. 2003 Indenter mechanism in geodynamics of the Crimean-Black-sea region. Forecast of HC and seismic hazard. — Kiev: Publishing house PP "EMKO", 2003. — 226 p. (in Russian).

Pivovarov, S.V. \& Derenyuk, N.E. (eds) 1984. Geological Map of the Crimea Mountains at a Scale of 1:200 000. UkrSSR Ministry of Geology, Kiev [in Russian].

Popadyuk, I.V. 2011. Crimea Mountains: the inversion? Of what? Abstracts of the 3rd International Symposium on the Geology of the Black Sea Region. Bucharest Romania, 137140.

Popadyuk, I.V., Stovba, S.M. and Khriachtchevskaia, O.I. 2013a. The New Geological map of the Crimea Mountains by SPK - Geoservice as a new approach to understanding the Black Sea Region. Abstracts of Darius Programme, Eastern Black Sea - Caucasus Workshop, 24-25 June, 2013, Tbilisi, Georgia, 48-50.

Popadyuk, I.V., Stovba, S.M. and Khriachtchevskaia, O.I. 2013b. The New Geological map of the Crimea Mountains M 1:200000 and its stratigraphical base. Abstracts of International scientific conference "Stratigraphiya osadochnyh obrazovaniy verhnego proterozoya $i$ fanerozoya”, Kyiv, 23-26 September, 2013, 117-118. 
Popadyuk, I.V., Stovba, S.M. and Khriachtchevskaia, O.I. 2014. Several comments for the paper of Sheremet, Ye., Sosson, M., Gintov, O., Muller, C., Yegorova, T. and Murovskaya, A., 2014. Key problems of stratigraphy of Crimea Mountains. New micropaleontological data on flysh rocks, Geophys. J., 36(2), 35-56 (in Russian). Geophys. J, 36(4), 149-151 (in Russian).

Pustovitenko, B. G. (ed.) 1991. Seismological Bulletin for the Western ESSN Zone (CrimeaCarpathians), 1970-1990. Naukova Dumka, Kiev [in Russian].

Pustovitenko, B. G. (ed.) 2010. Seismological Bulletin of Ukraine, 1991-2010. EKOSIGydrofizika, Simferopol [in Russian].

Pustovitenko, B. G., Eredzhepov, E. E. 2017. Focal parameters of 2016 Crimean-Black Sea region earthquakes // Uchenye zapiski Tavricheskogo nacional'nogo universiteta im. V. I. Vernadskogo; Geografiya. Geologiya. 2017, Tom 3(69), no.4, pp. 51-69 (in Russian).

Robertson, A., Parlak, O., Ustaömer, T., Taslı, K., İnan, N., Dumitrica, P. and Karaoğlan, F. 2014. Subduction, ophiolite genesis and collision history of Tethys adjacent to the Eurasian continental margin: new evidence from the Eastern Pontides, Turkey. Geodinamica Acta, 26, 230-293.

Robinson, A., Rudat, J. H., Banks, C. J. and Wiles, R. L. F. 1996. Petroleum geology of the Black Sea. Marine and Petroleum Geology, 13, 195-223.

Robinson, A.G. \& Kerusov, E. 1997. Stratigraphic and structural development of the Gulf of Odessa, Ukrainian Black Sea; implications for petroleum explorations. In: Robinson, A.G. (ed.) Regional and Petroleum Geology of the Black Sea and Surrounding Areas. AAPG Memoirs, 68, 369-380.

Rolland, Y., Perincek, D., Kaymakci, N., Sosson, M., Barrier, E. \& Avagyan, A. 2012. Evidence for 80-75 Ma subduction jump during Anatolide-Tauride-Armenian block accretion and 
48Ma 197 Arabia-Eurasia collision in Lesser Caucasus-East Anatolia. Journal of Geodynamics, 56, 7685.

Rud'ko, S.V., Kuznetsov, A.B. and Pokrovsky, B.G., 2017. Sr chemostratigraphy, $\delta 13$ C, and $\delta$ $18 \mathrm{O}$ of rocks in the Crimean carbonate platform (Late Jurassic, northern PeriTethys). Lithology and Mineral Resources, 52(6), pp.479-497.

Săndulescu, M., Kräutner, H., Borcoş, M., Năstăseanu, S., Patrulius, D., Stefănescu, M., Ghenea, C., Lupu, M., Savu, H., Bercia, I. and Marinescu, F., 1978. Geological map of Romania, scale 1: 1,000,000. Geol. Inst. of Rom., Bucharest.

Saintot, A., Angelier, J. \& Chorowicz, J. 1999. Mechanical significance of structural patterns identified by remote sensing studies: a multiscale analysis of tectonic structures in Crimea. Tectonophysics, 313, 187-218.

Saintot, A. \& Angelier, J. 2002. Tectonic paleostress fields and structural evolution of the NWCaucasus fold-and-thrust belt from Late Cretaceous to Quaternary. Tectonophysics, 357, 131.

Saintot, A., Stephenson, R.A., Stovba, S., Brunet, M.-F., Yegorova, T. \& Starostenko, V. 2006. The evolution of the southern margin of eastern Europe (Eastern European and Scythian platforms) from the latest Precambrian-Early Palaeozoic to the Early Cretaceous. In: Gee, D. \& Stephenson, R.A. (eds) European Lithosphere Dynamics. Geological Society, London, Memoirs 32, 481-505, http://doi.org/10. 1144/GSL.MEM.2006.032.01.30

Saintot, A., Stephenson, R.A. \& Chalot-Prat, F. 2007. The position of Crimea and Greater Caucasus along the active margin of Eurasia (from Early Jurassic to present). Abstract Volume, International Symposium on the Middle East Basins Evolution, 4-5 December, Paris, 69, 4-5. 
Seghedi, A., Vaida, M., Iordan, M. \& Verniers J., 2005. Paleozoic Evolution of the Romanian part of the Moesian platform : an overview, Geologica Belgica, 8, 4, 99-120.

Sengör, A. M. 1979. Mid-Mesozoic closure of Permo-Triassic Tethys and its implications. Nature, $279,590-593$.

Şengör, A. M. C. 1980. Mesozoic-Cenozoic tectonic evolution of Anatolia and surrounding regions. Bull Bur Rech Geol Minieres, France, 115-137.

Sengör, A. M. C. 1984. The Cimmeride Orogenic System and the Tectonics of Eurasia. Geological Society of America, Special Paper, 195, 81.

Şengör, A. M. C. et al 1985. Strike-slip faulting and related basin formation in zones of tectonic escape: Turkey as a case study.

Şengör, A. M. C. 1987. Tectonic subdivisions and evolution of Asia. Istanbul Teknik Universitesi Bulteni, 40(2), 355-435.

Sengör, A. M. C., Özeren, S. , Genc, T. , and Zor, E. . 2003. East Anatolian high plateau as a mantle-supported, north-south shortened domal structure, Geophys. Res. Lett., 30, 24, 8045, doi:10.1029/2003GL017858, 2003.

Sheremet, Y., Sosson, M., Gintov, O., Muller, C., Yegorova, T. and Murovskaya, A. 2014. Key problems of stratigraphy of Crimean Mountains. New micropaleontological data on flysch rocks, Geophys. J., 36, 2, 35-56 [in Russian].

Sheremet-Korniyenko Y., 2016. Structural analysis of the Eastern Crimean mountains (onlandoffshore) : consequence of the tectonic evolution of the northern margin of the eastern Black Sea,. Phd Thesis, University Côte d'Azur, Univ. de Nice Sophia -Antipolis., 250 p.

Sheremet, Y., Sosson, M., Gintov, O., Muller, C., Yegorova, T., Murovskaya, A. 2016a, Key problems of stratigraphy in the Eastern Crimea Peninsula, some insights from new dating and 
structural data. In: Sosson, M., Stephenson, R.A. and Adamia, S. A. (eds) Tectonic Evolution of the Eastern Black Sea and Caucasus. Geological Society, London, Special Publications, 428, pp.265-306

Sheremet, Y., Sosson, M., Ratzov, G., Sydorenko, G., Voitsitskiy, Z., Yegorova, T., Gintov, O. and Murovskaya, A., 2016b. An offshore-onland transect across the north-eastern Black Sea basin (Crimean margin): Evidence of Paleocene to Pliocene two-stage compression. Tectonophysics, 688, pp.84-100.

Sheremet, Y., Sosson, M., Seghedi, A. and Melinte-Dobrinescu, M.C., 2019. Northern Dobrogea and the Crimean Mountains: The Key Areas in the Tectonic Evolution of the Black Sea Basin. In The Structural Geology Contribution to the Africa-Eurasia Geology: Basement and Reservoir Structure, Ore Mineralisation and Tectonic Modelling (pp. 307-310). Springer, Cham.

Shniukova K.Ye, 2019. Subduction-related magmatism of the southern Crimea: offshore and onshore. Gologiya I korysni kopalyny Svitovogo okeanu. 15, n3, 33-243. [in Russian]

Slavin, V.I. 1986. New data about Sablynskaya formation of Lozovoya zone of the Crimea Mountains. Vestnik MGU, Geologiya, 4, 29-34 [in Russian].

Sludskij, A. 1917. New data on the geology and paleontologyof Karadag. Proceedings Karadag Scientific Station Name T.I. Viazemsky, 1, 27-32 [in Russian].

Sollogub, N.V. 1977. The structures of the Earth's crust of the Crimea according to GSS. Geophysical Collection, 77, 24-30 [in Russian].

Solov'ev, A.V. \& Rogov, M.A. 2010. The first zircon fission track dating of Mesozoic and Cenozoic complexes of the Crimea Peninsula. Stratigraphiya Geologicheskaja Korreljacija, 18, 74-82 [in Russian]. 
Sosson, M., Rolland, Y., Danelian, T., Muller, C., Melkonyan, R., Adamia, S., Kangarli, T., Avagyan, A., Galoyan, G., 2010. Subductions, obduction and collision in the Lesser Caucasus (Armenia Azerbaijan, Georgia), new insights. In: M. Sosson, N. Kaymakci, R. Stephenson, F. Bergarat, V. Starostenko (Eds.). Sedimentary Basin Tectonics from the Black Sea and Caucasus to the Arabian Platform. London: Geol. Soc. Spec. Publ., 340, 329-352.

Sosson, M., Stephenson, R., Sheremet, Y., Rolland, Y., Adamia, Sh., Melkonian, R., Kangarli, T., Yegorova, T., Avagyan, A., Galoyan, Gh., Danelian, T., Hässig, M., Meijers, M., Müller, C., Sahakyan, L., Sadradze, N., Alania, V., Enukidze, O., and Mosar, J. 2016. The eastern Black Sea-Caucasus region during the Cretaceous: New evidence to constrain its tectonic evolution. C. R. Geoscience, 348 (2016) 23-32. doi:10.1016/j.crte.2015.11.002

Sperner, B., and Zweigel. P., 2010. A plea for more caution in fault-slip analysis Tectonophysics, 482 (2010), 29-4. doi:10.1016/j.tecto.2009.07.019

Spiridonov, E.M., Fedorov, T.O. \& Ryakhovskii, V.M. 1990a. Magmatic rocks of the Crimea Mountains 1. Bulletin of the Moscow Society of Naturalists, Department of Geology, 65, 119134 [in Russian].

Spiridonov, E.M., Fedorov, T.O. \& Ryakhovskii, V.M. 1990b. Magmatic rocks of the Crimea Mountains 2. Bulletin of the Moscow Society of Naturalists, Department of Geology, 65, 102112 [in Russian].

Stampfli, G. M., \& Borel, G. D. 2002. A plate tectonic model for the Paleozoic and Mesozoic constrained by dynamic plate boundaries and restored synthetic oceanic isochrons. Earth and Planetary Science Letters, 196(1), 17-33. 
Stampfli, G. M., Borel, G. D., Cavazza, W., Mosar, J. \& Ziegler, P.A. 2001. Palaeotectonic and palaeogeographic evolution of the western Tethys and PeriTethyan domain (IGCP Project 369). Episodes, 24, 222-228.

Starostenko, V. Janik, T., Stephenson, R., Gryn, D., Rusakov, O., Czuba, W., Środa, P., Grad, M., Guterch, A., Flüh, E. and Thybo, H., 2017. DOBRE-2 WARR profile: the Earth's upper crust across Crimea between the Azov Massif and the northeastern Black Sea. Geological Society, London, Special Publications, 428(1), pp.199-220.

Stephenson, R. A., Mart, Y., Okay, A., Robertson, A. H. F., Saintot, A., Stovba, S. and KriachtchevskaiA, O. 2004. Transect VIII: Eastern European Craton to Arabian Craton (Red Star to Red Sea). In: W. Cavazza, F. M. Roure, W. Spakman, G. M. Stampfli and P. A. Ziegler (eds). The TRANSMED Atlas - The Mediterranean region from crust to mantle. Springer Verlag, Berlin, vol. XXIII, 120

Stephenson, R. A. and Schellart, W. 2010. The Black Sea back-arc basin: insights to its origin from geodynamic models of modern analogues. In: Sosson, M., Kaymakci, N., Stephenson, R. A., Bergerat, F. and Starostenko, V. (eds) Sedimentary Basin Tectonics from the Black Sea and Caucasus to the Arabian Platform. Geological Society, London, Special Publications, $340,11-21$.

Stovba, S., Khriachtchevskaia, O., and Popadyuk, I. 2009. Hydrocarbon-bearing areas in the eastern part of the Ukrainian Black Sea. Lead. Edge, 28(9), 1042-1045.

Stovba, S.M., Khriachtchevskaia, O.I, Popadyuk, I.V. 2012. Crimea and Ukrainian Eastern Black Sea Basin as an inverted Early Cretaceous rift. Abstracts, Darius Programme, Eastern Black Sea - Caucasus Workshop, 24-25 June 2013, Tbilisi, Georgia, 31-35. 
Stovba, S.M., Khriachtchevskaia, O.I, Popadyuk, I.V. 2013. Crimea and Ukrainian Eastern Black

Sea Basin as an inverted Early Cretaceous rift system. Abstracts of Darius Programme, Eastern Black Sea - Caucasus Workshop, 24-25 June, 2013, Tbilisi, Georgia.

Stratigraphy of the Ukrainian SSR, 1963.

Sydorenko, G., Stephenson, R., Yegorova, T., Starostenko, V., Tolkunov, A., Janik, T., ... \& Omelchenko, V. 2017. Geological structure of the northern part of the Eastern Black Sea from regional seismic reflection data including the DOBRE-2 CDP profile. Geological Society, London, Special Publications, 428, SP428-15.

Tan O., Taymaz T., 2006. Active tectonics of the Caucasus: Earthquake source mechanisms and rupture histories obtained from inversion of teleseismic body waveforms. Geological Society of America. Special Paper 409, 531-578.

Tari, G., Georgiev, G., Hardy, S., Poblet, J., \& Stefanescu, M. (1997). Late Triassic Cimmerian structures beneath the Moesian platform (romania/bulgaria). The Leading Edge, 16(8), 11531158.

Tari, G., Menlikli, C., Derman, S., 2011. Deepwater Play Types of the Black Sea: A Brief Overview. /Conference: AAPG Europe Regional Conference, Kiev 2010, At Kiev, Ukraine, Volume: Search and Discovery Article \#10310 (https://www.researchgate. net/publication/293175548_Deepwater_Play_Types_of_the_Black_Sea_A_Brief_Overview)

Tari, G., Schleder, Z., Kosi, W., Krezsek, C., Fallah, M. and Turi, V., 2015 Regional Structure of the Western Black Sea Basin: Map-view Kinematics. In International Conference \& Exhibition

Tari, G. C. and Simmons, M. D., 2018. History of deepwater exploration in the Black Sea and an overview of deepwater petroleum play types, in SIMMONS, M. D., TARI, G. C. \& OKAY, 
A. I. (eds) Petroleum Geology of the Black Sea. Geological Society, London, Special Publications, 464, https://doi.org/10.1144/SP464.1

Teslenko, JU.V. \& Yanovskaya, G.G. 1990. Middle Jurassic Flora of the Crimea Mountains. Naukova dumka, Kiev [in Russian].

Tkachuk, V.G. (ed.) 1970.Hydrogeology of the USSR.Vol. VIII. Crimea. Nedra, Moscow [in Russian]

Ushakov. S.A., Galushkin, Yu.1. and Ivanov, O.P., 1977. Nature of sedimentary folding at the Black Sea floor within the transition to Crimea and the Caucasus). Dokl. Akad. Nauk SSSR, 233(7): 932-934 [in Russian].

Ustaömer, T., \& Robertson, A. H. (1993). A Late Palaeozoic-Early Mesozoic marginal basin along the actives southern continental margin of Eurasia: Evidence from the central Pontides (Turkey) and adjacent regions. Geological journal, 28(3-4), 219-238.

Ustaömer, T., and Robertson, A. H. F. 1994. Late Palaeozoic marginal basin and subductionaccretion: the Palaeotethyan Küre complex, central Pontides, northern Turkey. Journal of the Geological Society, 151(2), 291-305.

van Hinsbergen, D. D., Torsvik, T. H., Schmid, S. M., Matenco, L. C., Maffione, M., Vissers, R. L., Gürer, D., Spakman, W. 2019. Orogenic architecture of the Mediterranean region and kinematic reconstruction of its tectonic evolution since the Triassic, Gondwana Research, in press, https://doi.org/10.1016/j.gr.2019.07.009

Vernyhorova, Y.V. and Ryabokon, T.S., 2020. The stratigraphy of the Oligocene-lower Miocene deposits of southern Ukraine // Turkish J Earth Sci (2020) 29: 170-207 doi:10.3906/yer-190524 
Vincent, S. J., W. Braham, V. A. Lavrishchev, J. R. Maynard, and M. Harland. 2016. The formation and inversion of the western Greater Caucasus Basin and the uplift of the western Greater Caucasus: Implications for the wider Black Sea region, Tectonics, 35, 2948-2962, doi:10.1002/ 2016TC004204.

Volfman, J.M. 2014. Deformation modes and kinematic conditions of the latest tectonic faulting within the Crimean Mountains. 1. Geophysical journal (36, number 6), 93-112. [in Russian].

Volfman, Yu.M. 2015. Deformational regimes and cinematic conditions of the newest tectonic faulting in the settings of the Crimea Mountains. Geophysical Journal, 37, 100-120 [in Russian].

Winchester, J. A., Pharaoh, T. C., Verniers, J., Ioane, D. and Seghedi, A., Dumitiu, I., 2006. Palaeozoic accretion of Gondwana-derived terranes to the East European Craton: recognition of detached terrane fragments dispersed after collision with promontories. In Gee, D. G., \& Stephenson, R. A. (eds) 2006. European Lithosphere Dynamics. Geological Society, London, Memoirs, 32, 323-332.

Yanovskaya, T.B., Gobarenko, V.S.,Yegorova, T.P.: Subcrustal structure of the Black Sea Basin from seismological data. Izv., Phys. Solid Earth 52, 14-28 (2016). DOI: $10.1134 / \mathrm{S} 1069351316010109$

Yamnychenko, I.M. (ed.) 1969. Stratigraphy of USSR. Jurassic. Naukova dumka, Kiev, 8 [in Russian].

Yegorova, T. and Gobarenko, V. 2010. Structure of the Earth's crust and upper mantle of Westand East-Black Sea Basins revealed from geophysical data and its tectonic implications. In: Sosson, M., Kaymakci, N., Stephenson, R., Bergerat, F. and Starostenko V. (Eds) Sedimentary 
Basin Tectonics from the Black Sea and Caucasus to the Arabian Platform. Geological

Society of London, Special Publications, 340, 23-42.

Yegorova, T. P., Baranova, E. P. and Omelchenko, V. D. 2010. The crustal structure of the Black

Sea from reinterpretation of deep seismic sounding data acquired in the 1960s. In: Sosson, M.,

Kaymakci, N., Stephenson, R. A., Bergerat, F. and Starostenko, V. (eds) Sedimentary Basin

Tectonics from the Black Sea and Caucasus to the Arabian Platform. Geological Society, London, Special Publications, 340, 43-56.

Yegorova, T. P Baranova, E.P., Gobarenko, V.S. and Murovskaya, A.V., 2018. Crustal Structure

of the Crimean Mountains along the Sevastopol-Kerch Profile from the Results of DSS and Local Seismic Tomography. Geotectonics, 52(4), pp.468-484.

Yilmaz, Y., Tuysuz, O., Yigitbas, E., Genc, S. C., \& Sengor, A. M. C. 1997. AAPG Memoir 68:

Regional and Petroleum Geology of the Black Sea and Surrounding Region. Chapter 11:

Geology and Tectonic Evolution of the Pontides.

Yudin, V. V. 2008. Geodynamic of the Black Sea-Caspian region. Kiev, UkrGGRI, 117p. [in Russian]

Yudin, V.V. 2009. Geologic Map and Sections of the Mountains, Foothill Crimea. Scale 1:200000. Soyuzkarta, Simferopol [in Russian].

Yudin, V. V. 2011. Geodynamics of the Crimea. DAIPI, Simferopol. [in Russian].

Zaika-Novackij, V.S., Guk, V.I., Nerodenko, V.M. \& Sokolov, I.P. 1976. The Geological Structure of the Crimean Foothills within Alma-Salhyrsk Watershed (Manual). Vishha shkola, Kiev [in Ukrainian].

Zaika-Novackij, V.S. 1981. On the age of volcanics of the Crimean foothills. Tektonika $i$ Stratigrafija, 21, 70-76 [in Russian]. 
Ziegler, P. 1988. Post-Hercynian plate reorganization in the Tethys and Arctic - North Atlantic domains. Developments in Geotectonics, 22, 711-755, https://doi.org/10.1016/j.crte.2012.01.006

Zolotarev, V.N. 1968. New data about late Triassic volcanism of the Central part of the Crimea Mountains. Reports of the Academy of Science of the USSR, 178, 4 [in Russian].

Zonenshain, L.P. et Le Pichon, X., 1986. Deep basins of the Black Sea and Caspian Sea as remnants of Mesozoic back-arc basins, Tectonophysics, 123, 181-211.

\section{Figure Captions}

Fig. 1: A - Structural sketch map of the Alpine belt in the Middle East sensu lato (modified from Sosson et al., 2016). The study area is framed by the red rectangle. 1: Platform, 2: European margin (Pontides), 3: European margin including magmatic arc (Pontides, Somkheto-Karabakh), 4: Lesser Caucasus units including ophiolites, 5: Anatolian ophiolites, 6: Metamorphic massifs, 7: Sakarya accreted terrane, 8: Taurides Anatolides South Armenian continental microplate, 9: Iran accreted terrane during Eo-Cimmerian orogeny, 10: Taurides Anatolides with obducted ophiolites and Peri-Arabic (Lycian nappes) including ophiolites, 11: Highly extended continental crust and oceanic crust, and 12: Mesozoic inverted basins (Greater Caucasus-Crimean Mountain Belt)

CACC : Central Anatolian crystalline complex, KM : Kirsehir massif, MM : Menderes massif, SM : Sakarya massif, IAES : Izmir-Ankara-Erzinkan suture, AESA : Ankara-ErzinkanSevan-Akera suture, NAF : North Anatolian fault, EAF : East Anatolian fault, GC : Greater Caucasus, LC : Lesser Caucasus, ATB : Adjara-Trialeti basin, SA : South Armenian block, C: Carpathian, D: Dobrogea, M: Moesia, SR: Shatsky Ridge, TT: Tuapse Trough, MBSH: 
Mid Black Sea High, K: Khoy ophiolites, V : Van Lake, S : Sevan Lake, and R : Rezaiyeh Lake

B: Structural schema containing major tectonic domains (coloured and labelled), regional tectonic units (labelled and separated by black lines) were compiled following Yegorova and Gobarenko (2010), Khriachtchevskaia et al. (2010), and Yegorova et al. (2018)

GC: Greater Caucasus, Lomonosov M: Lomonosov Massif, North Azov T: North Azov Trough, MBSR: Mid Black-Sea Ridge, CM: Crimean Mountain domain, TT: Tuapse Trough. The CM and the Kerch Peninsula (KP) are shown with main structures after Saintot et al. (2000), Sheremet et al. (2016), and Hippolyte et al. (2018) (see in details Fig. 5). Dashed lines correspond to fault zones: ASFZ: Alushta-Simferopol fault zone, WCF: Western Crimea Fault. White Line is a valley between the cities Simferopol (S) and Alushta (A). F: cape Fiolent, AT: cape Ay-Todor.

Fig. 2 Proposed compiled map of the CM based on a geological map (Ed. Muratov, 1967 from Popadyuk et al., 2013a) and structural geological map of the ECM (Sheremet et al. (2016a). The limit between them is shown by black dotted line. Red circles indicate locations of samples redated based on the analysis of foraminifera published in Popadyuk et al. $(2013,2014)$ as Albian in age. Black: the outcrop studied by Popadyuk et al. (2013). Yellow circles: locations of samples redated by nannofossils (from Sheremet et al., 2016a).

Fig. 3 Schematic stratigraphic logs of the Crimean Mountains supplemented from Sheremet et al. (2016a). 
Fig. 4 Geological cross sections with interpretation through the WCM and ECM. Location of the cross-sections is shown in Fig. 5.

Fig. 5 Map of tectonic structures of the CM and of the KP juxtaposed on the shaded relief map of the CM and the KP and compiled map of the CM (Fig. 2). For the KP we used the map of Muratov (Ed. 1967) (the CMs' part of this map is shown in the side-bar). The cross-sections shown in Fig. 4.

Fig. 6 A: Example of the south vergence folding in the northern part of the Ordzhonikidze, cape between Koktebel and Feodosiya

B: Example of right-lateral strike slip fault in the Upper Jurassic limestones, Kokasan canyon, SW of Belogorsk, East of site 34 on Figure 4.

C: Normal fault in the westernmost part of the Dolgorukovskaya Yayla (Druzhnoye village). a: interpreted fragment of the general view b; f: fractures, accompanying the normal faulting, d: zoom-view on red carbonated material filled up the fractures.

D: Syndepositional faults in the Middle Eocene nummulitic limestones: a, b: Michurinskoe village (eastwards from Belogorsk); c-e: Belaya Skala (northwards of the Belogorsk).

Fig. 7 Hypocenters at different depths: (1) 0-15 km, (2)15-30 km, (3) more than $30 \mathrm{~km}$; (4) CSZ subzones (1, Sevastopol; 2, Yalta-Alushta; 3, Sudak; 4, Kerch-Taman) (from Yegorova et al., 2018); (5) seismic stations (ALU, Alushta; ANN, Anapa; DON, Donuzlav; FEO, Feodosiya; KERU, Kerch; SEV, Sevastopol; SIM, Simferopol; SUDU, Sudak; TARU, Tarkhankut; YAL, Yalta); (6) isolines corresponding to depths of Cretaceous basement, km; (7) location of thrusts in the Sorokin Trough based on seismic line interpretation (Shermet et al., 2016b) and main structures of the CM (Fig. 5); (8) main fault zones: WCF and ASFZ; (9) location of the interpreted seismic 
lines used for geological transects (Fig. 8) (from Sheremet et al., 2016b); (10) profiles of seismic records shown on Fig. 8 (number 4 in legend); and (11) focal mechanisms of strong earthquakes in the Black Sea northern coastal area (from Gobarenko et al., 2016). Colour of line (10) coincides with the colour of the numbers of focal mechanisms located along this line.

Fig. 8 Distribution of week seismicity records $(M \leq 3)$, within the Crimean Seismic Zone, CSZ) during 1970-2013 (from Yegorova et al., 2018) (A) along the geological transects through the ECM and the Sorokin Trough (from Sheremet et al., 2016b) and (B) along the geological cross sections through the WCM (from Fig. 4) and beneath the sea-bottom line as the prolongation of those cross-sections in the BS.

Legend 8A and B: 1: hypocenters of the seismic events; 2: sea-bottom line; 3: geological crosssections (Fig. 4, Fig. 5), 4: profiles of seismic records, their location is shown on figure 7 (number 10 in legend), 5: presumable location of rupture zones. 6: focal mechanism in vertical crosssection, number of the seismic event located on the map of the figure 7.

Fig. 9. A: Local palaeo-stress tensor for NW-SE Palaeocene-Early Eocene and NS post-Miocene compressions imprinted in the ECM and Kerch Peninsula. The red plane in the stereo-diagrams corresponds to the bedding of the site. The characteristics of palaeo-stress are shown in the Table Different colours of the flashes mark different groups of the palaeo-stress regimes.

B: Local palaeo-stress tensors for the Pliocene-Quaternary time compression imprinted in the ECM and Kerch Peninsula. The characteristics of palaeo-stress is shown in the Table 2.

C: Local palaeo-stress tensors for the extensional stress-field of the ECM. The characteristics of palaeo-stress is shown in the Table 2. 
Fig. 10 Reconstruction of a WSW-ESE oriented cross section through the ECM for the Early Cretaceous.

Fig. 11. Palaeoreconstructive sketch for Crimea during the Cenozoic N-S compression, showing the role of indenter in formation of the corresponding structures in the vicinity of the Crimean part of the northern Black Sea margin. Light grey faults correspond to the Triassic (or older) structures. Legend: SR: Shatsky Ridge, MBSR: Middle Black Sea Ridge, ASFZ: Alushta-Simferopol Fault Zone, PCFZ: Pecenega-Camena Fault Zone (prolongation of the Teisseyre-Tornquist zone), KT: Kerch-Taman Trough; TT: Tuapse Trough WCF: Western Crimea Fault, EBSB: Eastern Black Sea Basin; WBSB: Western Black Sea Basin. B: formation of the Sorokin Trough; C: Undethrusting beneath the northern margin of the Black Sea

\section{Tables}

Table 1. Parameters of focal mechanisms of strong earthquakes in the Black Sea's northern coastal area (selected and supplemented from Gobarenko et al. 2016, Pustovitenko and Eredzhepov, 2017). Serial number corresponds to number of earthquake mechanism in Fig. 7 and Fig. 8.

Table 2. Reverse, strike-slip, and extensional regimes obtained for the ECM, illustrated in Fig. 4. Nd: Number of fault data, R: Stress ratio $(\sigma 2-\sigma 3) /(\sigma 1-\sigma 3)$, CD: Counting Deviation in \%, (Delvaux and Spencer, 2003). 

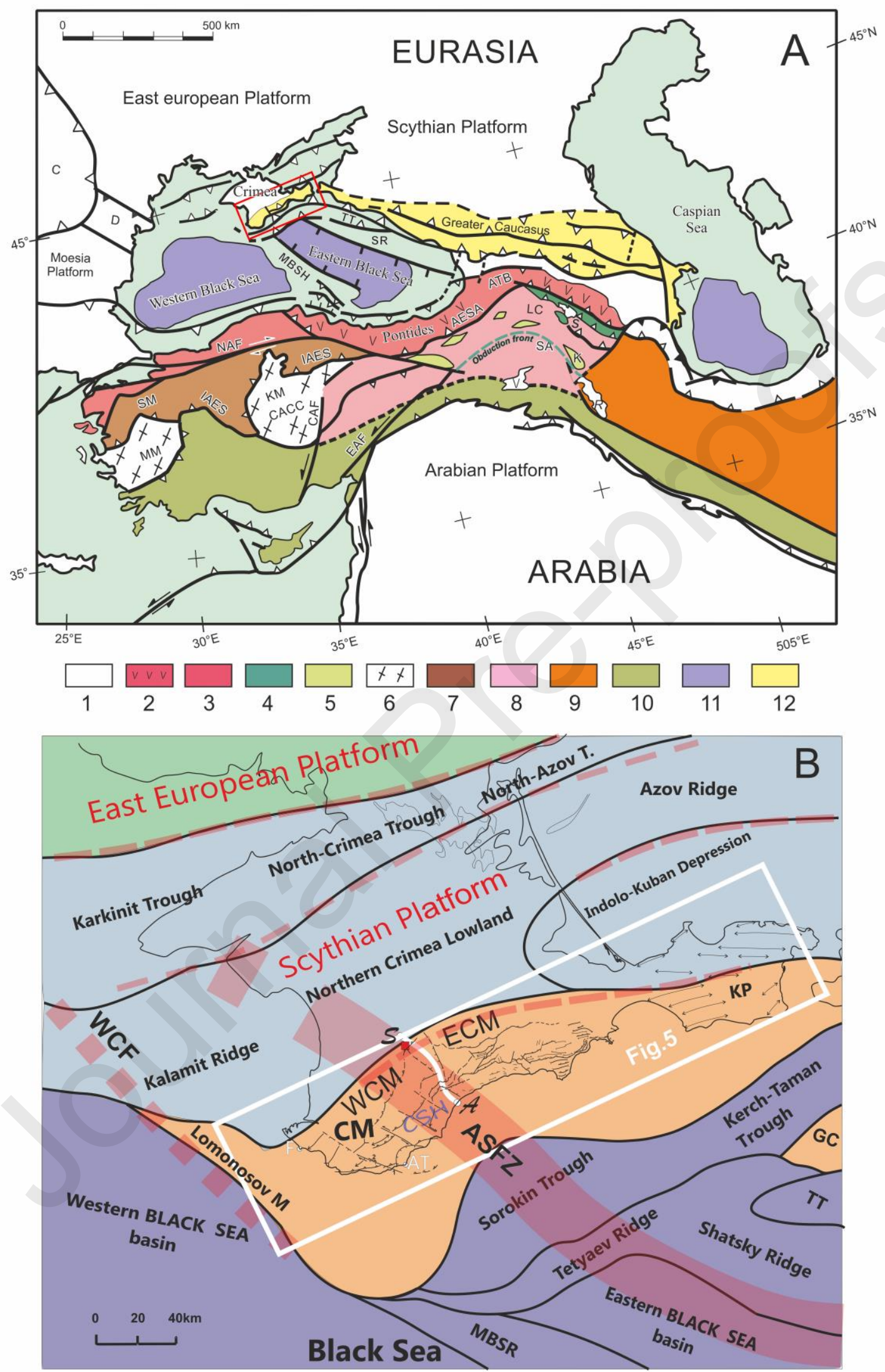
Journal Pre-proofs

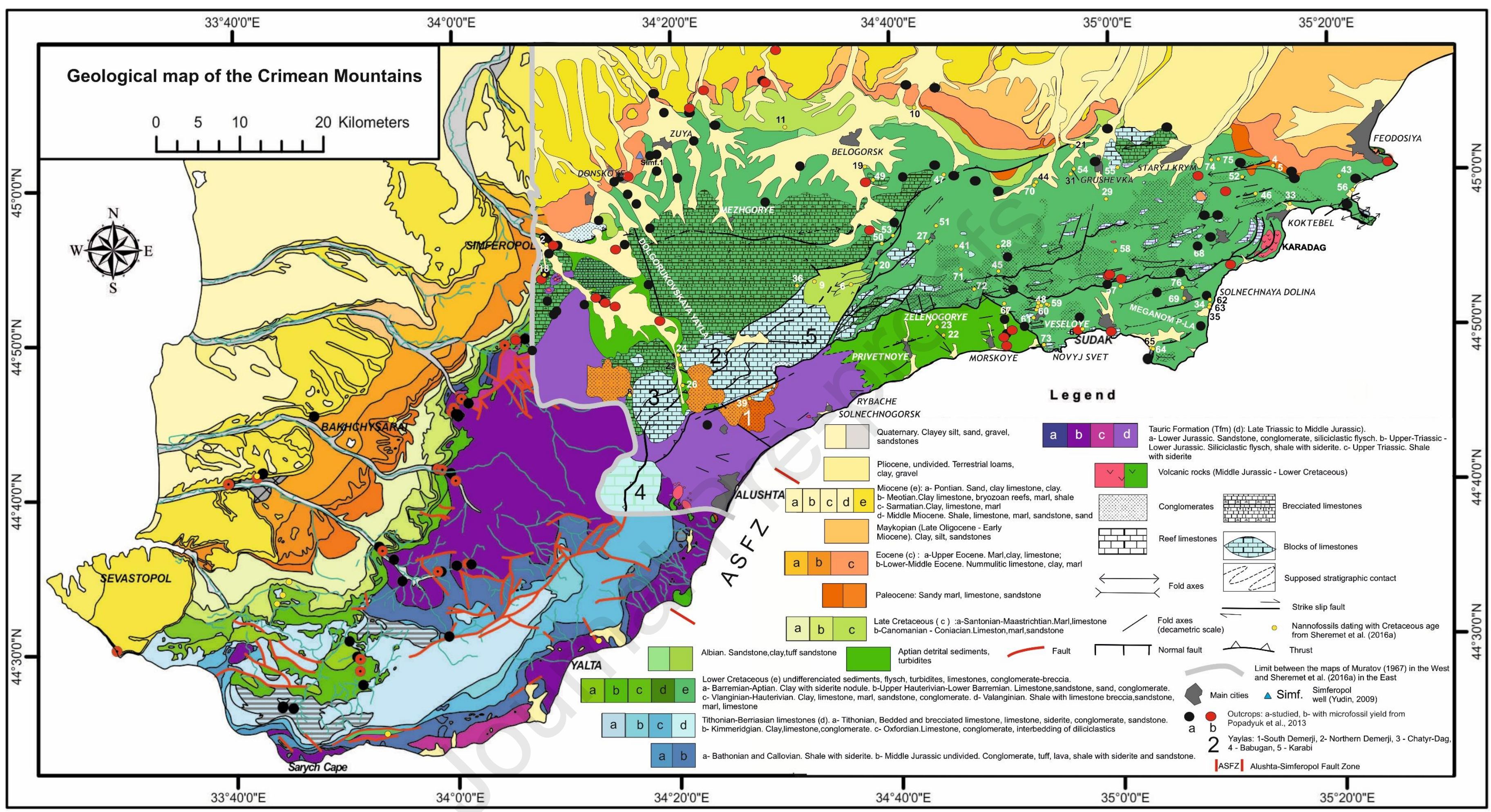




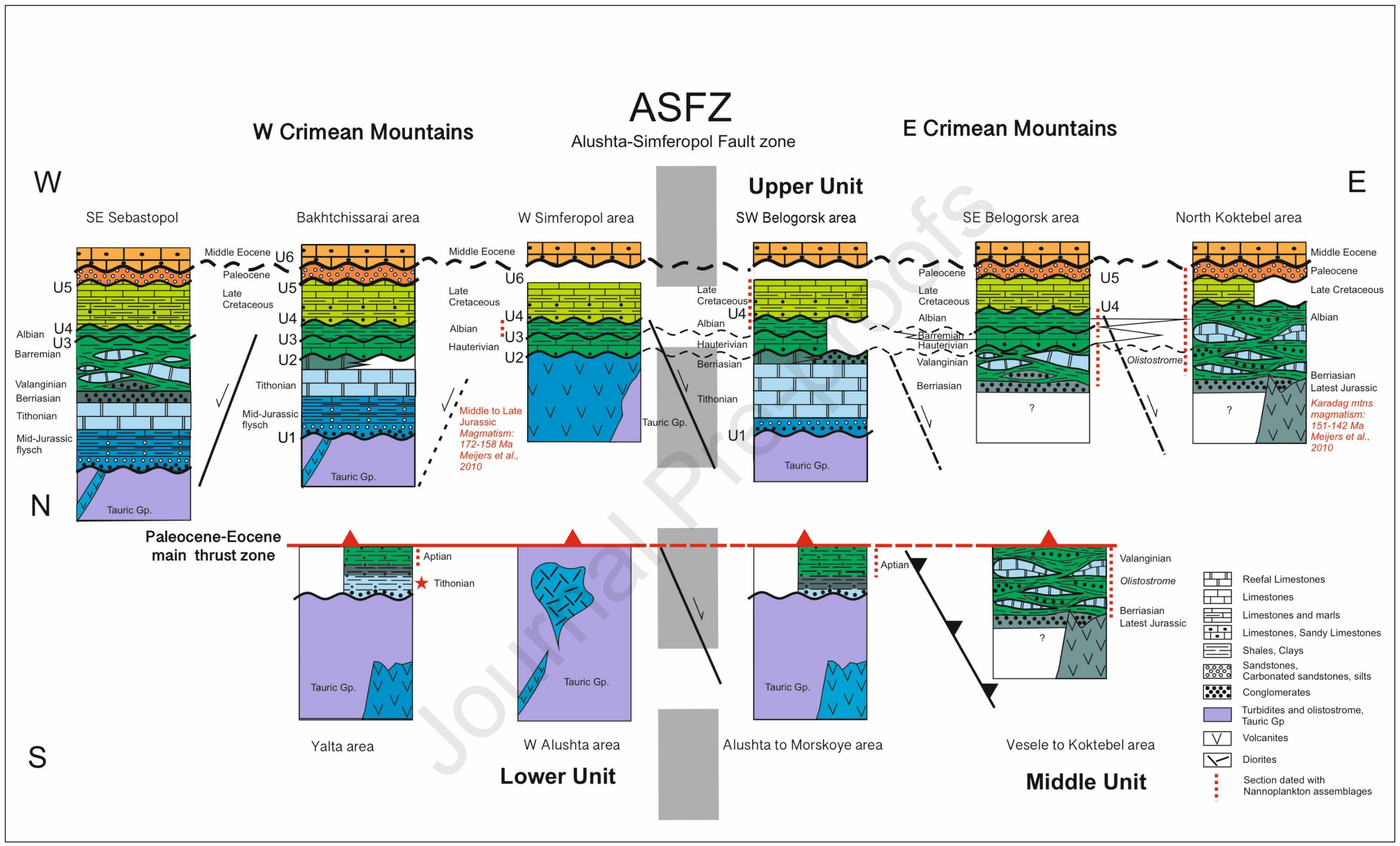




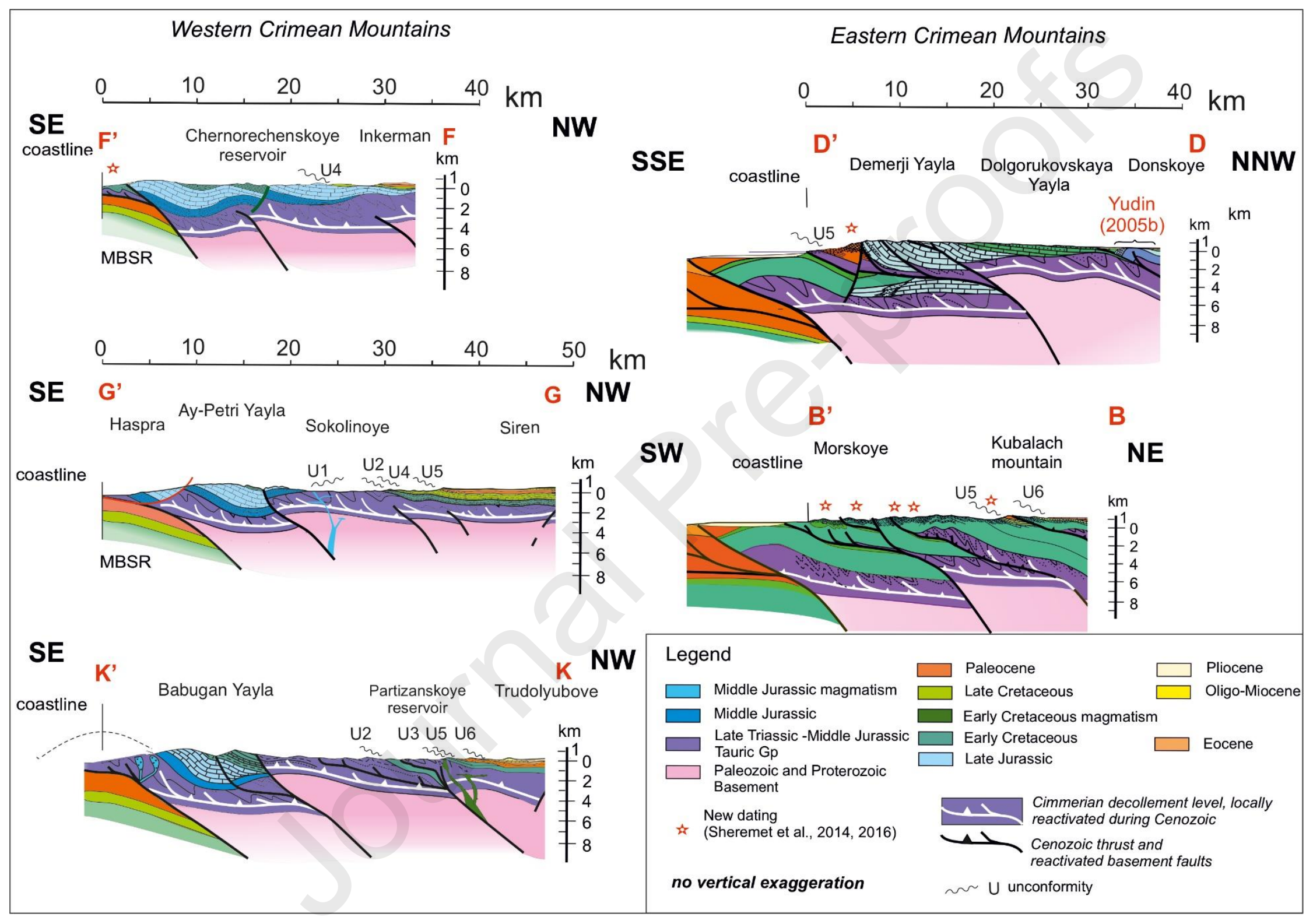




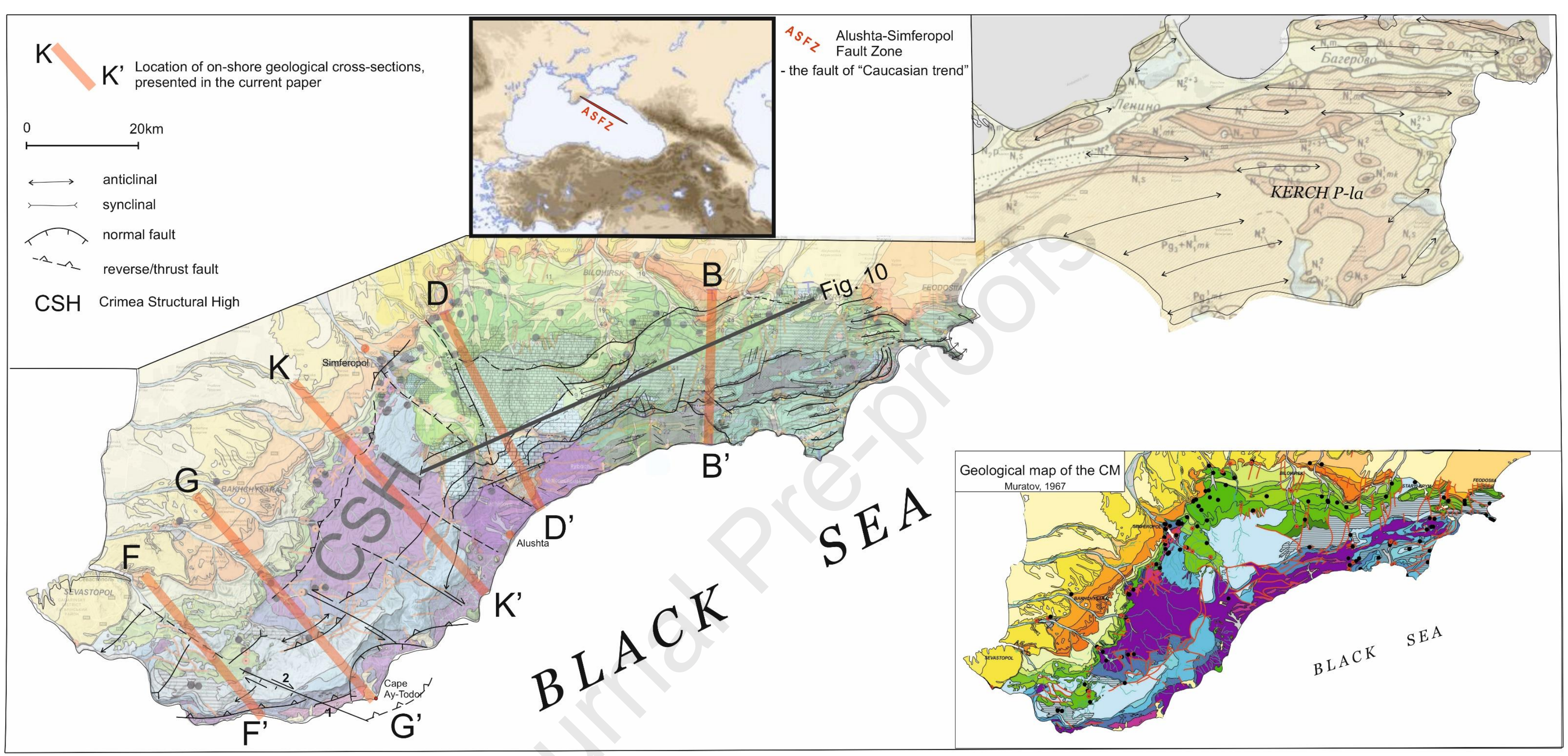




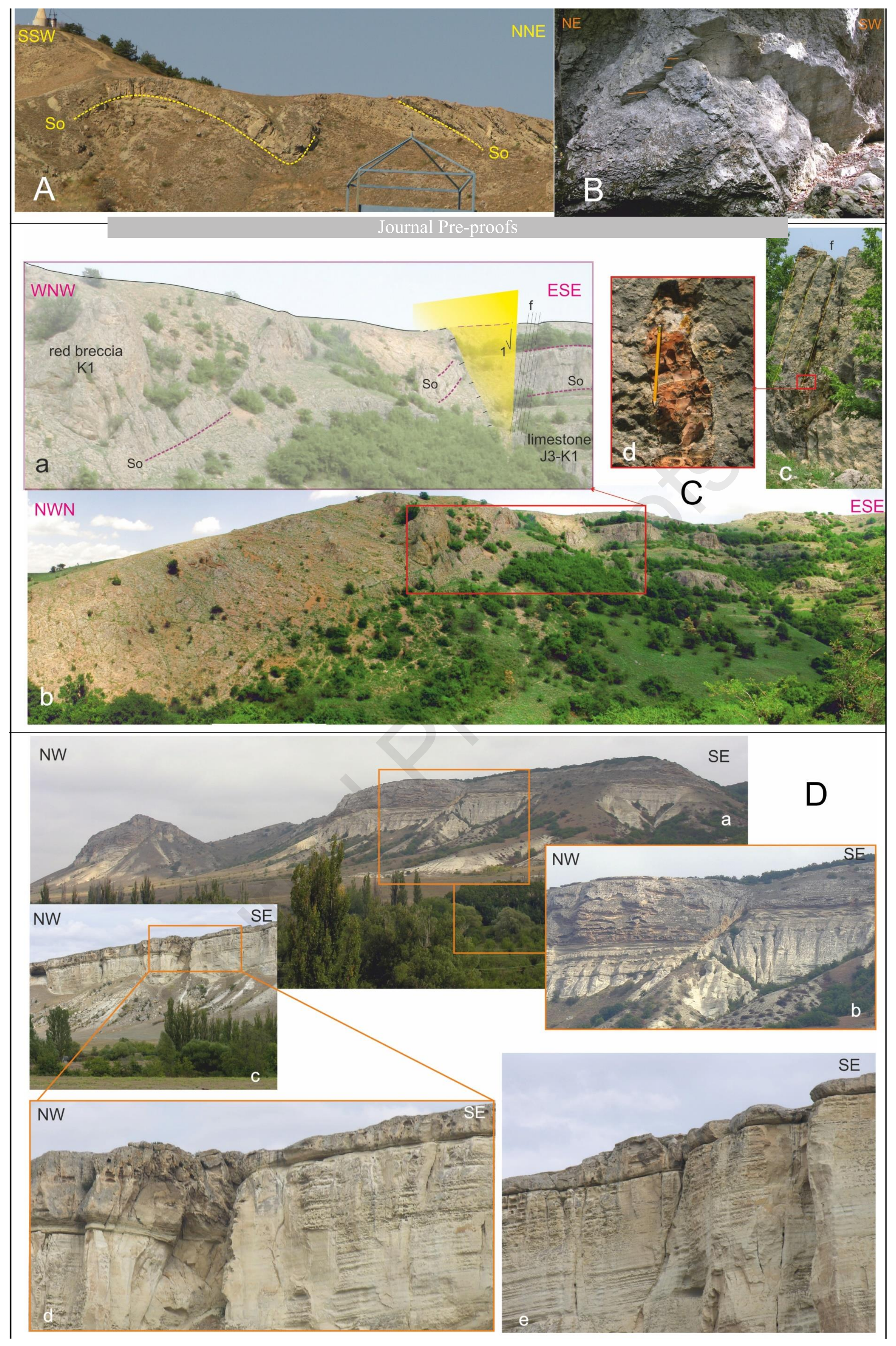


A

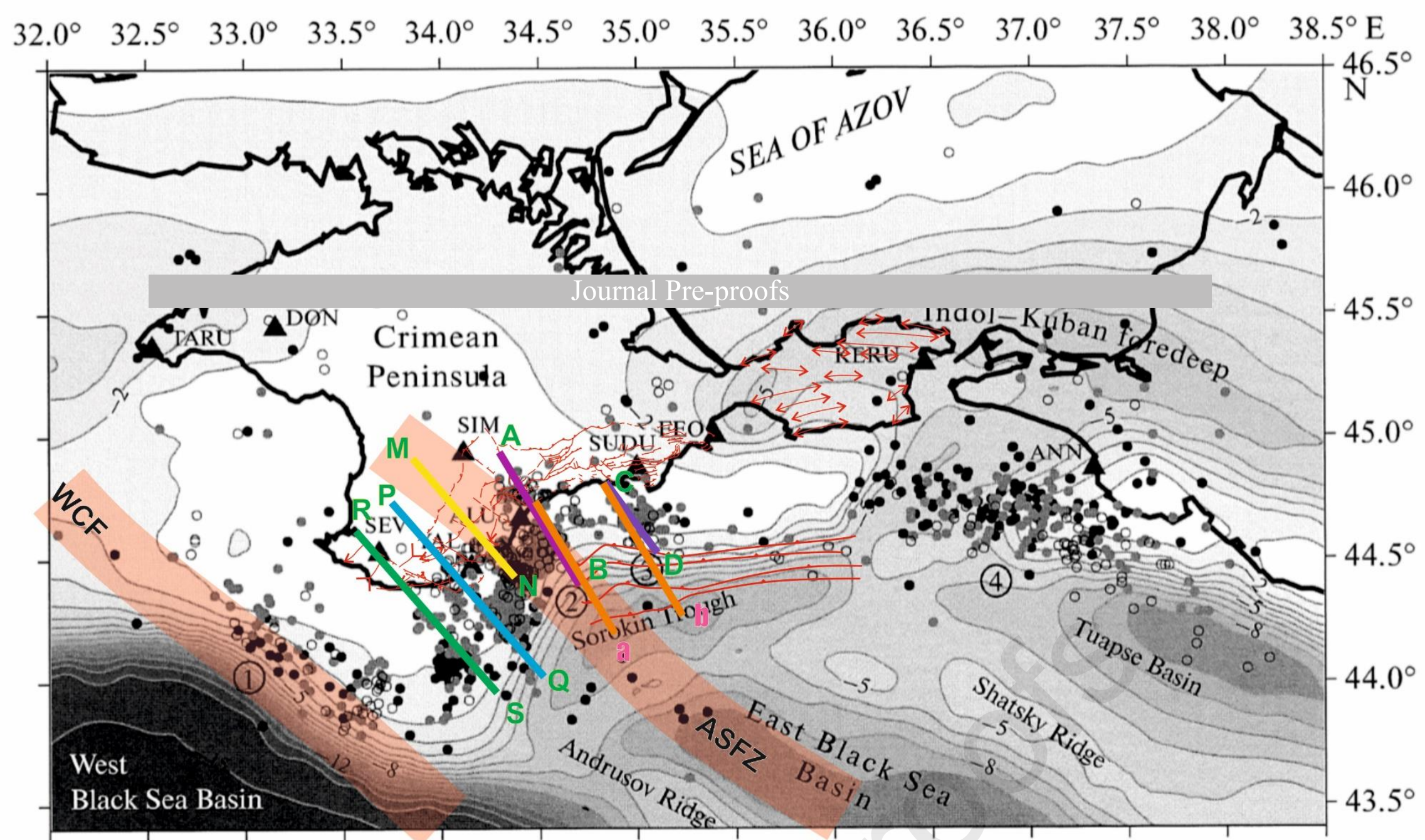

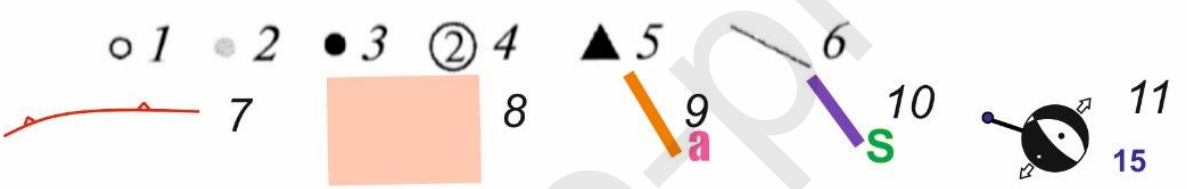

B

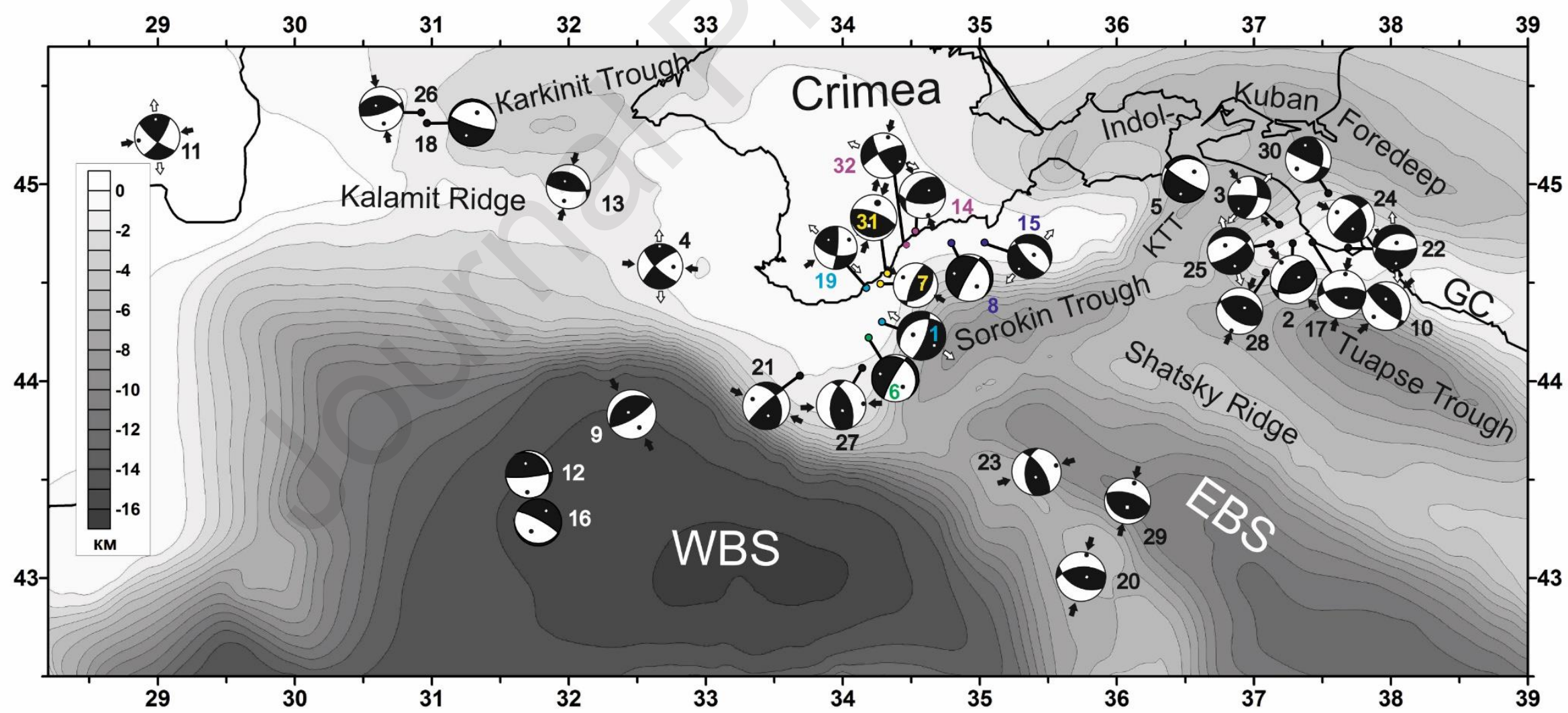


A
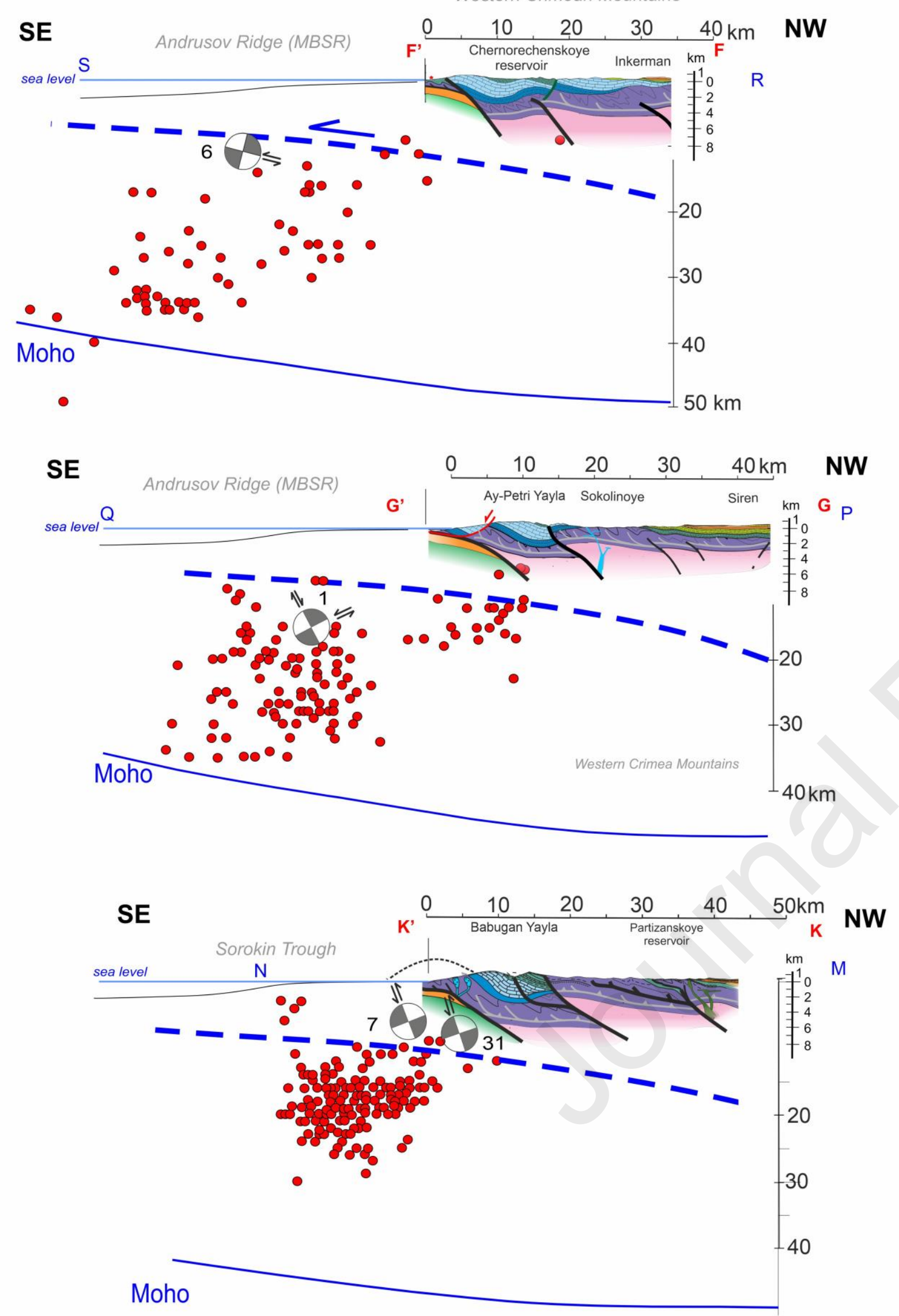

B
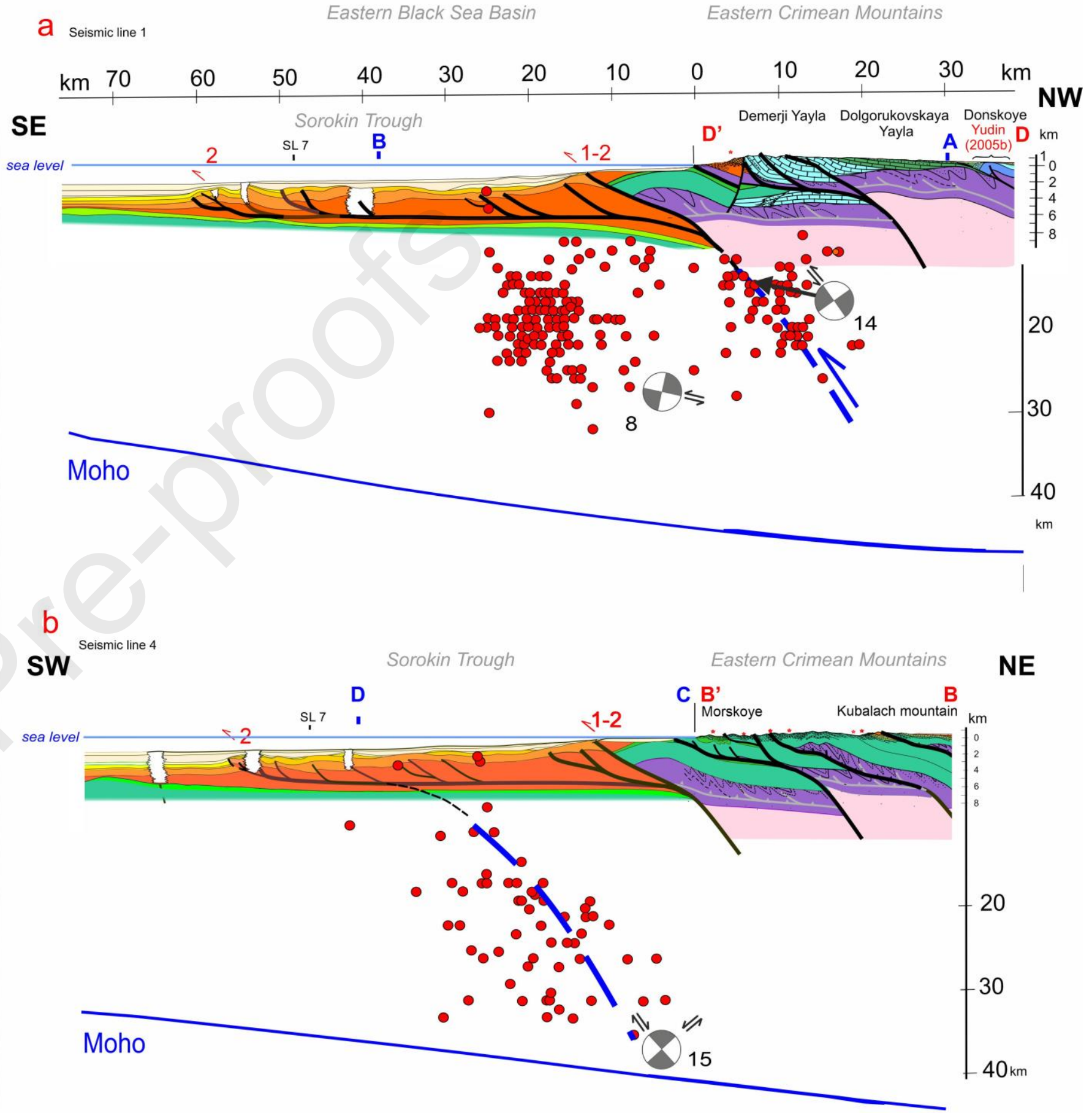

LEGEND (A,B)
- 1
D'D 3
BA 4

56




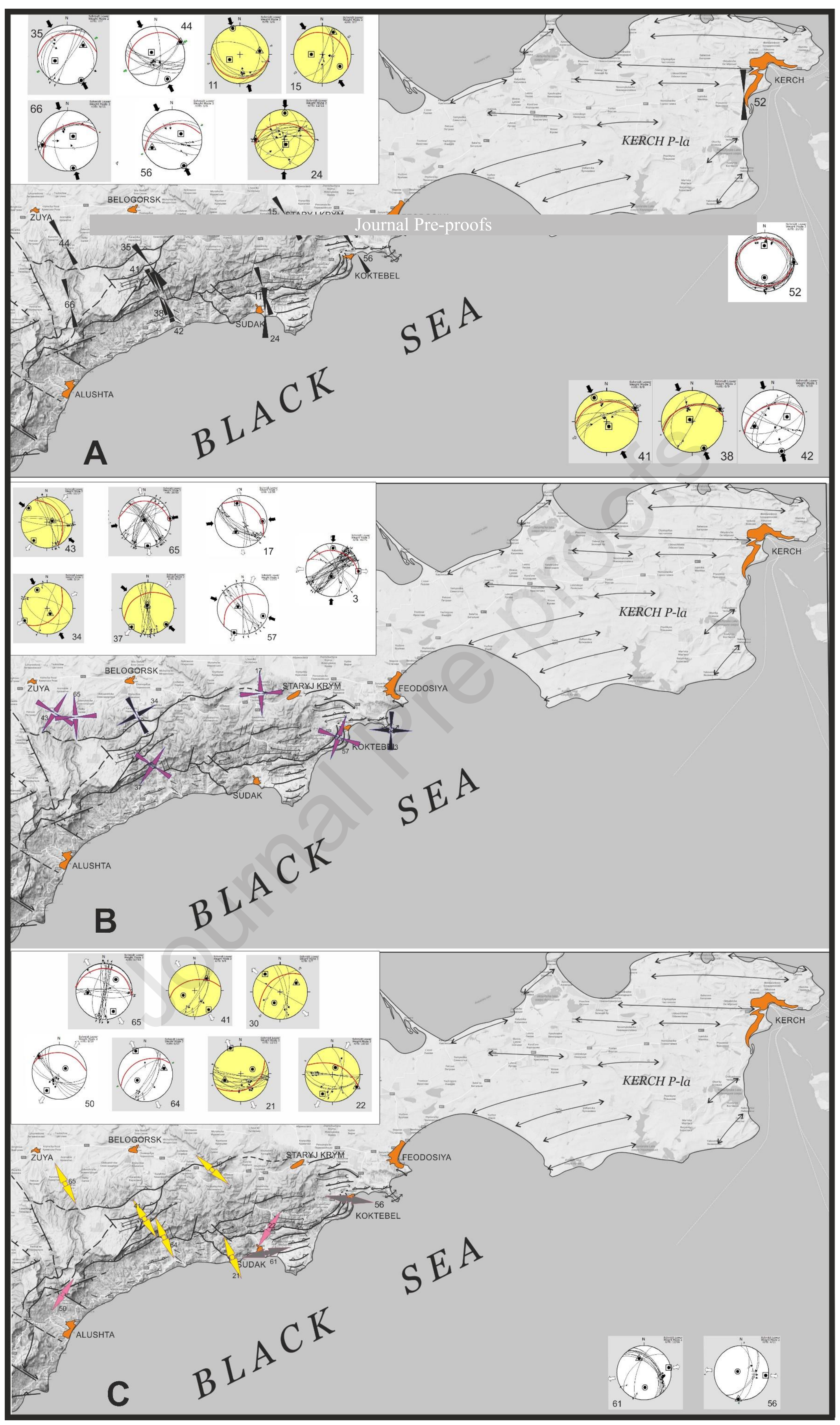




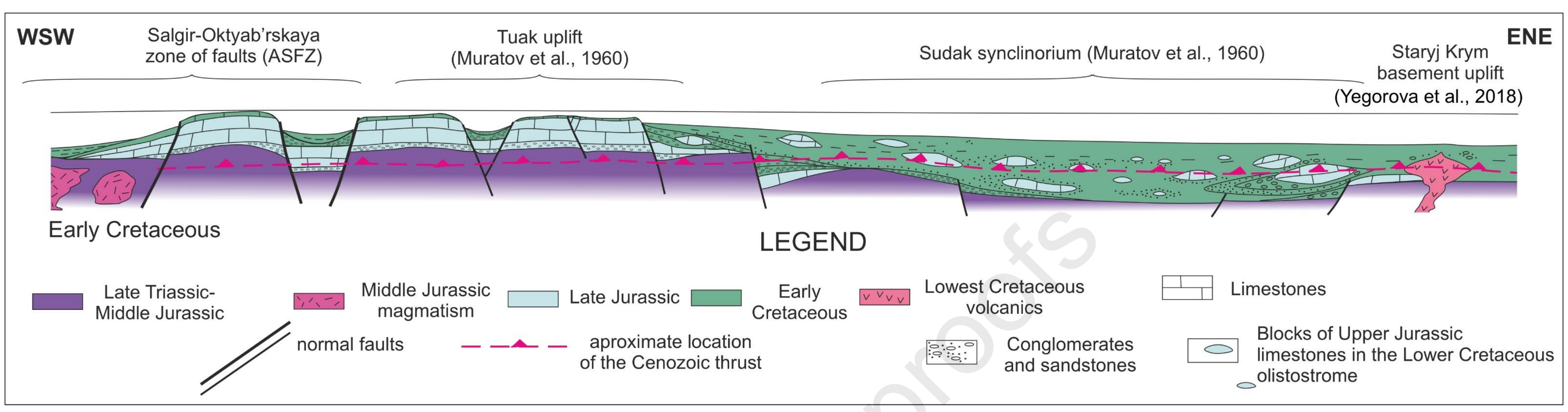



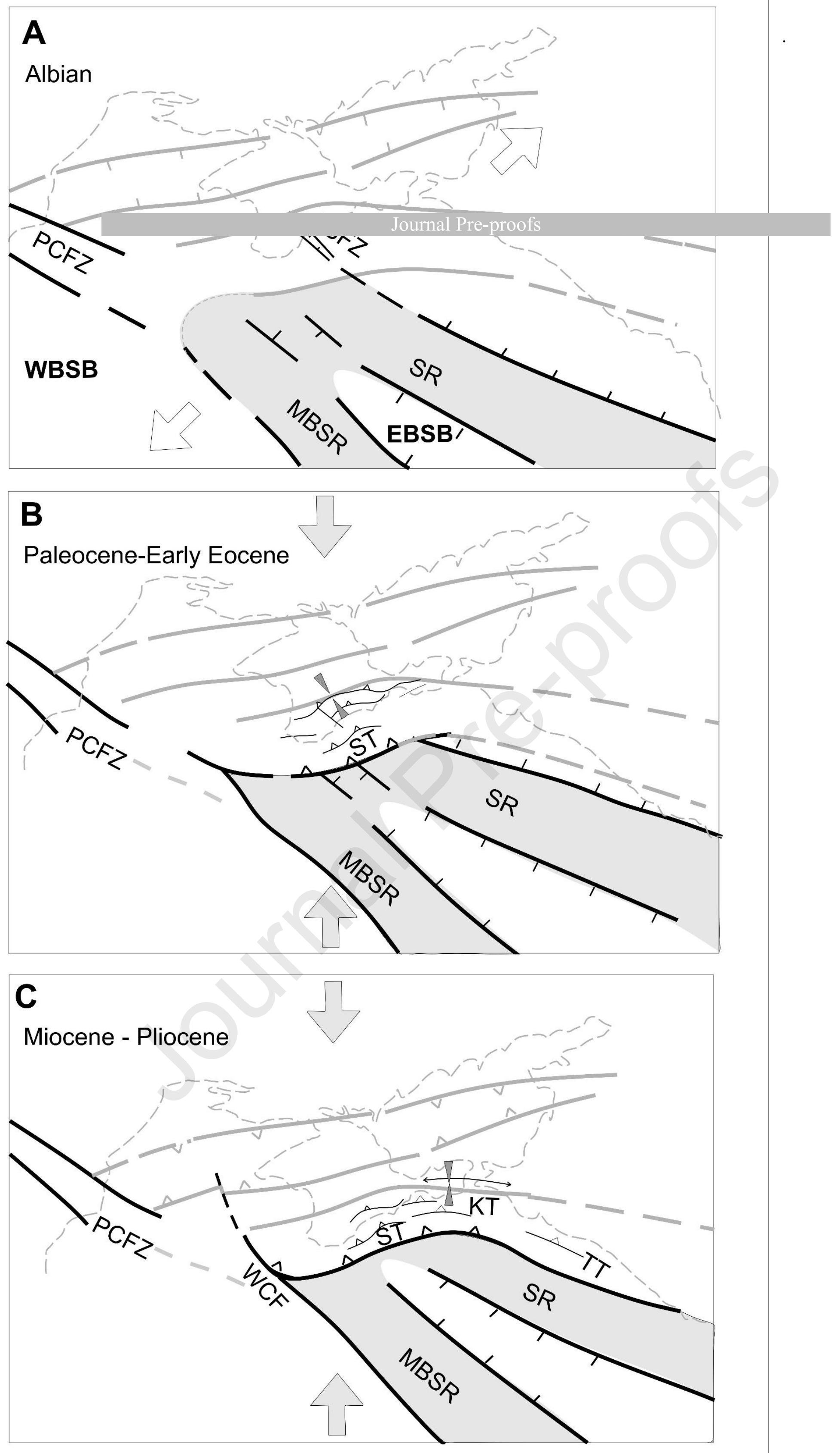
Table 1. Parameters of focal mechanisms of strong earthquakes in the Black Sea's northern coastal area (selected and supplemented from Gobarenko et al. 2016, Pustovotenko and Eredzhepov, 2017). Serial number corresponds to number of earthquake mechanism in Fig. 7 and

\begin{tabular}{|c|c|c|c|c|c|c|c|c|c|c|}
\hline No & Date & $\begin{array}{l}\text { Latitu } \\
\text { de, N }\end{array}$ & $\begin{array}{l}\text { Long } \\
\text { itude, } \\
\text { E }\end{array}$ & $\begin{array}{l}\text { Depth } \\
\text {, km }\end{array}$ & $\begin{array}{l}\text { Azimuth } \\
\text { and dip of } \\
\text { contraction } \\
\text { axis, P }\end{array}$ & $\begin{array}{l}\text { Azimuth } \\
\text { and dip of } \\
\text { intermedia } \\
\text { te axis, } N\end{array}$ & $\begin{array}{l}\text { Azimuth } \\
\text { and dip of } \\
\text { extension } \\
\text { axis T }\end{array}$ & $\begin{array}{l}\text { Magnit } \\
\text { ude, } \\
\text { Mw }\end{array}$ & $\begin{array}{l}\text { Deform } \\
\text { ation } \\
\text { mechan } \\
\text { ism }\end{array}$ & $\begin{array}{l}\text { Structural } \\
\text { position }\end{array}$ \\
\hline 1 & $\begin{array}{l}11.09 \\
.1927\end{array}$ & 44.3 & 34.3 & 15 & $263 / 62$ & $28 / 17$ & $125 / 22$ & 6.9 & $\begin{array}{l}\text { Normal } \\
\text { fault }\end{array}$ & $\begin{array}{l}\text { Continenta } \\
1 \text { slope, } \\
\text { south } \\
\text { Crimea }\end{array}$ \\
\hline 6 & $\begin{array}{l}1955- \\
1975\end{array}$ & 44.2 & 34.2 & 15 & $134 / 54$ & $29 / 11$ & $292 / 34$ & 2.5 & Thrust & $\begin{array}{l}\text { Continenta } \\
1 \text { slope, } \\
\text { south } \\
\text { Crimea }\end{array}$ \\
\hline 7 & $\begin{array}{l}1955- \\
1975\end{array}$ & 44.5 & 34.3 & 5 & $301 / 29$ & $204 / 13$ & $92 / 58$ & 2.5 & $\begin{array}{l}\text { Revers } \\
\mathrm{e}\end{array}$ & $\begin{array}{l}\text { Continenta } \\
1 \text { slope, } \\
\text { Southern } \\
\text { Crimea }\end{array}$ \\
\hline 8 & $\begin{array}{l}1955- \\
1975\end{array}$ & 44.7 & 34.8 & 20 & $134 / 54$ & $29 / 11$ & $292 / 34$ & 2.5 & Thrust & $\begin{array}{l}\text { Continenta } \\
1 \text { slope, } \\
\text { South- } \\
\text { Eastern } \\
\text { Crimea }\end{array}$ \\
\hline 14 & $\begin{array}{l}02.07 \\
1990\end{array}$ & 44,78 & 3453 & 14 & $160 / 8$ & $254 / 28$ & $55 / 61$ & 4.7 & $\begin{array}{l}\text { Revers } \\
\text { e }\end{array}$ & $\begin{array}{l}\text { Mountain } \\
\text { Crimea }\end{array}$ \\
\hline 15 & $\begin{array}{l}16.08 \\
.1990\end{array}$ & 44.7 & 35.06 & 28 & $81 / 67$ & $317 / 14$ & $223 / 19$ & 4.7 & Normal & $\begin{array}{l}\text { Continenta } \\
1 \text { slope, } \\
\text { South- } \\
\text { Eastern } \\
\text { Crimea } \\
\end{array}$ \\
\hline 19 & $\begin{array}{l}22.11 \\
.1996\end{array}$ & 44.51 & 34.16 & 10 & $61 / 16$ & $173 / 52$ & $320 / 34$ & 3.2 & $\begin{array}{l}\text { Strike- } \\
\text { slip }\end{array}$ & $\begin{array}{l}\text { Mountain } \\
\text { Crimea }\end{array}$ \\
\hline 31 & $\begin{array}{l}15.10 \\
.2013\end{array}$ & 44,55 & 34,35 & 7 & $16 / 27$ & $108 / 6$ & $209 / 62$ & 3.4 & $\begin{array}{l}\text { Revers } \\
\mathrm{e}\end{array}$ & $\begin{array}{l}\text { Mountain } \\
\text { Crimea }\end{array}$ \\
\hline 32 & $\begin{array}{l}13.05 \\
.2016\end{array}$ & 44,63 & 34,41 & 13 & $10 / 200$ & $67 / 315$ & $20 / 106$ & 3.5 & $\begin{array}{l}\text { Strike- } \\
\text { slip }\end{array}$ & $\begin{array}{l}\text { Continenta } \\
1 \text { slope, } \\
\text { south } \\
\text { Crimea }\end{array}$ \\
\hline
\end{tabular}

Fig. 8 . 
Table 2. Reverse, strike-slip, and extensional regimes obtained for the ECM, illustrated in Fig. 4.

Nd: Number of fault data, $R$ : Stress ratio $(\sigma 2-\sigma 3) /(\sigma 1-\sigma 3), C D$ : Counting Deviation in \%,

(Delvaux and Spencer, 2003).

\begin{tabular}{|c|c|c|c|c|c|c|c|c|c|c|c|c|c|c|}
\hline \multirow{13}{*}{$\begin{array}{l}\text { Compres } \\
\text { sional } \\
\text { regime } \\
\text { with } \\
\mathrm{NW}-\mathrm{SE} \\
\text { to N-S } \\
\sigma_{1}\end{array}$} & \multirow{2}{*}{$\begin{array}{l}\mathrm{Re} \\
\mathrm{f} . \\
\mathrm{N} \\
\mathrm{o}\end{array}$} & \multirow[t]{2}{*}{ Place } & \multirow{2}{*}{$\begin{array}{l}\text { Latitude/ } \\
\text { Longitude } \\
\text { In degrees }\end{array}$} & \multirow{2}{*}{$\begin{array}{l}\text { Stratigraph } \\
\text { ic age }\end{array}$} & \multirow{2}{*}{$\begin{array}{l}\text { Litholo } \\
\text { gy }\end{array}$} & \multirow[t]{2}{*}{$\mathrm{Nd}$} & \multirow[t]{2}{*}{$\mathrm{R}$} & \multicolumn{2}{|l|}{$\sigma_{1}$} & \multicolumn{2}{|l|}{$\sigma_{2}$} & \multicolumn{2}{|c|}{$\sigma 3$} & \multirow{2}{*}{$\begin{array}{l}\mathrm{CD} \\
\%\end{array}$} \\
\hline & & & & & & & & Dir. & $\begin{array}{l}\text { Plun } \\
\text { g. }\end{array}$ & Dir. & $\begin{array}{l}\text { Plu } \\
\text { ng. }\end{array}$ & Dir. & $\begin{array}{l}\text { Plu } \\
\text { ng. }\end{array}$ & \\
\hline & 35 & $\begin{array}{l}\text { Krasnoselo } \\
\text { vka }\end{array}$ & $\begin{array}{l}34,635167 \\
44,918167\end{array}$ & $\begin{array}{l}\text { LOWER } \\
\text { CRETACE } \\
\text { OUS }\end{array}$ & Flysch & 7 & 0.44 & 148 & 8 & 59 & 37 & 243 & 53 & 24.6 \\
\hline & 41 & $\begin{array}{l}\text { Belogorsk- } \\
\text { Privetnoe }\end{array}$ & $\begin{array}{l}34,6345 \\
44,9011\end{array}$ & $\begin{array}{l}\text { LOWER } \\
\text { CRETACE } \\
\text { OUS }\end{array}$ & Flysch & 8 & 0.75 & 334 & 13 & 64 & 0 & 155 & 77 & 23.8 \\
\hline & 42 & $\begin{array}{l}\text { Belogorsk- } \\
\text { Privetnoe }\end{array}$ & $\begin{array}{l}34,6351 \\
44,901\end{array}$ & $\begin{array}{l}\text { LOWER } \\
\text { CRETACE } \\
\text { OUS }\end{array}$ & Flysch & 13 & 0.33 & 164 & 2 & 255 & 38 & 72 & 52 & 23.7 \\
\hline & 56 & Koktebel & $\begin{array}{l}35,278133 \\
44,969050\end{array}$ & $\begin{array}{l}\text { LOWER } \\
\text { CRETACE } \\
\text { OUS }\end{array}$ & Flysch & 6 & 0.25 & 156 & 4 & 248 & 29 & 58 & 61 & 19.7 \\
\hline & 11 & $\begin{array}{l}\text { Sudak- } \\
\text { Dachnoye }\end{array}$ & $\begin{array}{l}35,000633 \\
44,886433\end{array}$ & $\begin{array}{l}\text { LOWER } \\
\text { CRETACE } \\
\text { OUS }\end{array}$ & $\begin{array}{l}\text { Flysch, } \\
\text { conglo } \\
\text { merate } \\
\mathrm{s}\end{array}$ & 6 & 0.17 & 345 & 7 & 79 & 31 & 244 & 58 & 23.3 \\
\hline & 15 & $\begin{array}{l}\text { Strayj } \\
\text { Krym }\end{array}$ & $\begin{array}{l}35,0905 \\
45,047017\end{array}$ & $\begin{array}{l}\text { LOWER } \\
\text { CRETACE } \\
\text { OUS- } \\
\text { UPPER } \\
\text { CRETACE } \\
\text { OUS }\end{array}$ & $\begin{array}{l}\text { Conglo } \\
\text { merate } \\
\mathrm{s}, \\
\text { limesto } \\
\text { nes }\end{array}$ & $\nabla$ & 0.7 & 123 & 27 & 26 & 14 & 272 & 59 & 18.8 \\
\hline & 24 & $\begin{array}{l}\text { Kapsel- } \\
\text { Sudak }\end{array}$ & $\begin{array}{l}34,997 \\
44,8373\end{array}$ & $\begin{array}{l}\text { LOWER } \\
\text { CRETACE } \\
\text { OUS }\end{array}$ & Flysch & 12 & 0.6 & 1 & 13 & 270 & 4 & 164 & 77 & 24.5 \\
\hline & 38 & $\begin{array}{l}\text { Belogorsk- } \\
\text { Privetnoe }\end{array}$ & $\begin{array}{l}34,634 \\
44,911667\end{array}$ & $\begin{array}{l}\text { LOWER } \\
\text { CRETACE } \\
\text { OUS }\end{array}$ & Flysch & 6 & 0.58 & 156 & 7 & 66 & 4 & 310 & 82 & 15.9 \\
\hline & 66 & Karaby & $\begin{array}{l}34,486667 \\
44,966667\end{array}$ & $\begin{array}{l}\text { UPPER } \\
\text { JURASSIC }\end{array}$ & $\begin{array}{l}\text { Limest } \\
\text { one }\end{array}$ & 6 & 0.58 & 168 & 9 & 261 & 17 & 50 & 71 & 20.5 \\
\hline & 44 & Mezhgorye & $\begin{array}{l}34,415 \\
44,991\end{array}$ & $\begin{array}{l}\text { LOWER } \\
\text { CRETACE } \\
\text { OUS }\end{array}$ & $\begin{array}{l}\text { Limest } \\
\text { one }\end{array}$ & 12 & 0.71 & 152 & 14 & 61 & 4 & 316 & 75 & 21 \\
\hline & 52 & $\begin{array}{l}\text { Kerch, } \\
\text { Arshyncev } \\
\text { o }\end{array}$ & $\begin{array}{l}36.47 \\
45.30\end{array}$ & MIOCENE & $\begin{array}{l}\text { Limest } \\
\text { one }\end{array}$ & 21 & 0.52 & 181 & 47 & 90 & 1 & 359 & 43 & 24 \\
\hline $\begin{array}{l}\text { Strike- } \\
\text { slip } \\
\text { regime } \\
\text { (SSR) } \\
\text { with E- } \\
W \sigma_{1}\end{array}$ & 17 & Grushevka & $\begin{array}{l}35,005383 \\
45,0162\end{array}$ & $\begin{array}{l}\text { UPPER } \\
\text { JURASSIC }\end{array}$ & $\begin{array}{l}\text { Limest } \\
\text { one }\end{array}$ & 12 & 0,29 & 114 & 28 & 207 & 54 & 348 & 30 & 22.2 \\
\hline $\begin{array}{l}\text { SSR } \\
\text { with } \\
\text { NW-SE } \\
\sigma_{1}\end{array}$ & 37 & $\begin{array}{l}\text { Belogorsk- } \\
\text { Privetnoye } \\
\text { road }\end{array}$ & $\begin{array}{l}34.635 \\
44.91\end{array}$ & $\begin{array}{l}\text { LOWER } \\
\text { CRETACE } \\
\text { OUS }\end{array}$ & $\begin{array}{l}\text { Flysch, } \\
\text { limesto } \\
\text { nes }\end{array}$ & 9 & 0.5 & 131 & 8 & 350 & 80 & 222 & 6 & 14.1 \\
\hline $\begin{array}{l}\text { SSR } \\
\text { with } \\
\text { NW-SE } \\
\sigma_{1} \\
\end{array}$ & 43 & Mezhgorye & $\begin{array}{l}34.415 \\
44.991\end{array}$ & $\begin{array}{l}\text { LOWER } \\
\text { CRETACE } \\
\text { OUS }\end{array}$ & $\begin{array}{l}\text { Limest } \\
\text { one, } \\
\text { flysch }\end{array}$ & 11 & 0.55 & 308 & 12 & 76 & 71 & 215 & 14 & 19.7 \\
\hline $\begin{array}{l}\text { SSR } \\
\text { with }\end{array}$ & 57 & Karadag & $\begin{array}{l}35.2151 \\
44.9546\end{array}$ & $\begin{array}{l}\text { LOWER } \\
\text { CRETACE }\end{array}$ & $\begin{array}{l}\text { Volcan } \\
\text { ics, }\end{array}$ & 13 & 0.5 & 110 & 17 & 292 & 73 & 200 & 01 & 20 \\
\hline
\end{tabular}




\begin{tabular}{|c|c|c|c|c|c|c|c|c|c|c|c|c|c|c|}
\hline $\begin{array}{l}\text { NW-SE } \\
\sigma_{1}\end{array}$ & & & & OUS & $\begin{array}{l}\text { limesto } \\
\text { ne }\end{array}$ & & & & & & & & & \\
\hline $\begin{array}{l}\text { SSR } \\
\text { with E- } \\
W \sigma_{1}\end{array}$ & 65 & Mezhgorye & $\begin{array}{l}34.415 \\
44.991\end{array}$ & $\begin{array}{l}\text { UPPER } \\
\text { JURASSIC } \\
\text {-LOWER } \\
\text { CRETACE } \\
\text { OUS }\end{array}$ & $\begin{array}{l}\text { Limest } \\
\text { one, } \\
\text { flysch }\end{array}$ & 26 & 0.56 & 83 & 1 & 339 & 84 & 173 & 6 & 17.7 \\
\hline $\begin{array}{l}\text { SSR } \\
\text { with N-S } \\
\sigma_{1}\end{array}$ & 3 & $\begin{array}{l}\text { Ordjonikid } \\
\text { ze and } \\
\text { Feodosiya }\end{array}$ & $\begin{array}{l}35.34911 \\
44.96933\end{array}$ & $\begin{array}{l}\text { LOWER } \\
\text { CRETACE } \\
\text { OUS }\end{array}$ & Flysch & 40 & 0.57 & 2 & 19 & 189 & 71 & 93 & 2 & 21.2 \\
\hline $\begin{array}{l}\text { SSR } \\
\text { with } \\
\text { NW-SE } \\
\sigma_{1}\end{array}$ & 34 & $\begin{array}{l}\text { Ulyanovka, } \\
\text { open pit }\end{array}$ & $\begin{array}{l}34,634 \\
45,0101\end{array}$ & $\begin{array}{l}\text { UPPER } \\
\text { JURASSIC } \\
\text {-LOWER } \\
\text { CRETACE } \\
\text { OUS }\end{array}$ & $\begin{array}{l}\text { Limest } \\
\text { one }\end{array}$ & 5 & 0.4 & 332 & 19 & 150 & 71 & 242 & 1 & 23.3 \\
\hline \multirow[t]{5}{*}{$\begin{array}{l}\text { Extensio } \\
\text { nal } \\
\text { regime } \\
\text { (ER) ER } \\
\text { with } \\
\text { NW-SE } \\
\text { б3 }\end{array}$} & 21 & Novyj Svet & $\begin{array}{l}34,90055 \\
44,82065\end{array}$ & $\begin{array}{l}\text { LOWER } \\
\text { CRETACE } \\
\text { OUS- } \\
\text { UPPER } \\
\text { JURASSIC }\end{array}$ & $\begin{array}{l}\text { Limest } \\
\text { one, } \\
\text { flysch }\end{array}$ & 12 & 0,67 & 69 & 52 & 248 & 38 & 338 & 0 & 21.4 \\
\hline & 30 & $\begin{array}{l}\text { Bogatoye- } \\
\text { Bor Kaya }\end{array}$ & $\begin{array}{l}34,8529 \\
45,0127\end{array}$ & $\begin{array}{l}\text { PALEOCE } \\
\text { NE, } \\
\text { UPPER } \\
\text { CRETACE } \\
\text { OUS }\end{array}$ & $\begin{array}{l}\text { Limest } \\
\text { one, } \\
\text { marls, } \\
\text { sandy } \\
\text { limesto } \\
\text { nes }\end{array}$ & 5 & 0.3 & 208 & 53 & 61 & 32 & 320 & 16 & 19.6 \\
\hline & 41 & $\begin{array}{l}\text { Belogorsk- } \\
\text { Privetnoye }\end{array}$ & $\begin{array}{l}34,6345 \\
44,9011\end{array}$ & $\begin{array}{l}\text { LOWER } \\
\text { CRETACE } \\
\text { OUS }\end{array}$ & Flysch & 5 & 0.5 & 247 & 51 & 45 & 37 & 330 & 29 & 18.7 \\
\hline & 64 & $\begin{array}{l}\text { Belogorsk- } \\
\text { Privetnoye }\end{array}$ & $\begin{array}{l}34,639 \\
44,909\end{array}$ & $\begin{array}{l}\text { LOWER } \\
\text { CRETACE } \\
\text { OUS }\end{array}$ & Flysch & 6 & 0.75 & 235 & 60 & 72 & 29 & 338 & 7 & 20.2 \\
\hline & 65 & Mezhgorye & $\begin{array}{l}34.415 \\
44.991\end{array}$ & $\begin{array}{l}\text { LOWER } \\
\text { CRETACE } \\
\text { OUS- } \\
\text { UPPER } \\
\text { JURASSIC }\end{array}$ & $\begin{array}{l}\text { Limest } \\
\text { one, } \\
\text { Flysch }\end{array}$ & 17 & 0.68 & 44 & 40 & 266 & 42 & 155 & 22 & 23 \\
\hline \multirow[t]{2}{*}{$\begin{array}{l}\text { ER with } \\
\mathrm{NE}- \\
\mathrm{SW} \sigma 3\end{array}$} & 22 & Dachnoye & $\begin{array}{l}35.0006 \\
44.88643\end{array}$ & $\begin{array}{l}\text { LOWER } \\
\text { CRETACE } \\
\text { OUS }\end{array}$ & $\begin{array}{l}\text { Conglo } \\
\text { merate } \\
\mathrm{s}\end{array}$ & 10 & 0.72 & 22 & 67 & 117 & 2 & 207 & 23 & 23.6 \\
\hline & 50 & Demerji & $\begin{array}{l}34,3958 \\
44,7519\end{array}$ & $\begin{array}{l}\text { PALEOCE } \\
\text { NE (?) }\end{array}$ & $\begin{array}{l}\text { Conglo } \\
\text { merate } \\
\mathrm{s}\end{array}$ & 8 & 0.56 & 58 & 69 & 307 & 8 & 42 & 15 & 14.6 \\
\hline \multirow[t]{2}{*}{$\begin{array}{l}\text { ER with } \\
\text { E-W } \sigma 3\end{array}$} & 56 & Koktebel & $\begin{array}{l}35,278133 \\
44,969050\end{array}$ & $\begin{array}{l}\text { LOWER } \\
\text { CRETACE } \\
\text { OUS }\end{array}$ & Flysch & 4 & 0.38 & 292 & 78 & 186 & 3 & 96 & 11 & 13.4 \\
\hline & 61 & $\begin{array}{l}\text { Alchak- } \\
\text { Kapsel }\end{array}$ & $\begin{array}{l}34,992050 \\
44,836683\end{array}$ & $\begin{array}{l}\text { UPPER } \\
\text { JURASSIC }\end{array}$ & $\begin{array}{l}\text { Limest } \\
\text { one }\end{array}$ & 12 & 0.5 & 176 & 45 & 341 & 44 & 78 & 7 & 13.3 \\
\hline
\end{tabular}



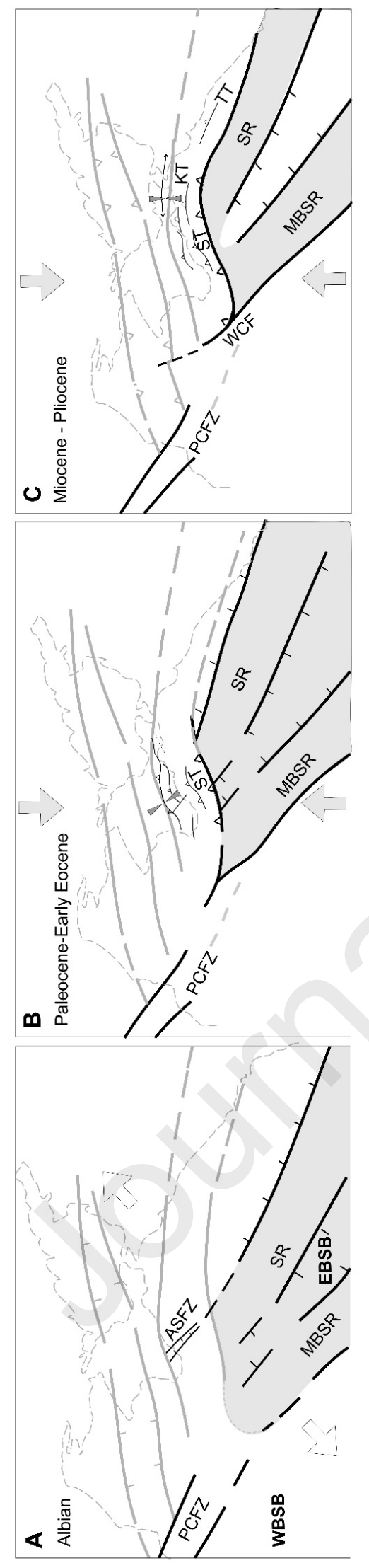
Highlights

1) The Crimean Mtns (CM) are divided into two parts by a NW-SE oriented main fault zone

2) Two systems of E-W and of NW-SE oriented faults were reactivated since the Cretaceous.

3) The reactivated structures control the Cenozoic inversion of CM

4) The model shows the major role of indenter during the Cenozoic inversion 


\section{CRediT author statement}

YEVGENIYA SHEREMET: Conceptualization, Methodology, Investigation, Writing - Original Draft

MARC SOSSON: Supervision, Funding acquisition, Project administration

ANNA MUROVSKAYA: Investigation, writing precisions

VALENTINA GOBARENKO: Methodology, Investigation

TAMARA YEGOROVA: Project administration, writing precisions 


\section{Declaration of interests}

$\bigotimes$ The authors declare that they have no known competing financial interests or personal relationships that could have appeared to influence the work reported in this paper.

$\square$ The authors declare the following financial interests/personal relationships which may be considered as potential competing interests: 